\title{
Properties of Piezoelectric Ceramics in the Solid-Solution Series Lead Titanate-Lead Zirconate-Lead Oxide: Tin Oxide and Lead Titanate-Lead Hafnate
}

\author{
B. Jaffe, ${ }^{2}$ R. S. Roth, and S. Marzullo
}

\begin{abstract}
Compositional proximity to a morphotropic transformation between two ferroelectric solid-solution phases seems to yield ceramic transducers having desirable properties over a wide range of temperature. Examples of this phenomenon were observed in the systems $\mathrm{PbTiO}_{3}-\mathrm{PbZrO}_{3}, \mathrm{PbTiO}_{3}-\mathrm{PbO}: \mathrm{SnO}_{2}, \mathrm{PbTiO}_{3}-\mathrm{PbZrO} \mathrm{O}_{3}-\mathrm{PbO}: \mathrm{SnO}_{2}$, and $\mathrm{PbTiO}_{3}-\mathrm{PbHfO}_{3}$. The dielectric and piezoelectric properties of ceramics having compositions in these systems and in the system $\mathrm{PbZrO}_{3}-\mathrm{PbO}: \mathrm{SnO}_{2}$ are described.

The composition $\mathrm{Pb}\left(\mathrm{Ti}_{.45} \mathrm{Zr}_{.55}\right) \mathrm{O}_{3}$ exhibits a high radial coupling coefficient, greater than 0.3 , for temperatures as high as $275^{\circ} \mathrm{C}$ and has the highest $\mathrm{g}_{31}$ constant, $11.7 \times 10^{-3}$ volt-meters per newton. For the series of compositions containing 30 percent $\mathrm{PbO}: \mathrm{SnO}_{2}$ in the ternary system $\mathrm{PbTiO}_{3}-\mathrm{PbZrO}_{3}-\mathrm{PbO}: \mathrm{SnO}_{2}$ the tetragonal composition nearest the morphotropic boundary has the highest $d_{31}$ value, $74 \times 10^{-12}$ coulombs per newton. The rhombohedral composition nearest the morphotropic boundary shows the least change of frequency constant with temperature, a 2 percent variation over the range of $25^{\circ}$ to $225^{\circ} \mathrm{C}$.
\end{abstract}

\section{Introduction}

Piezoelectric ceramic transducers can be fabricated in a wide variety of shapes and sizes. Like other ceramics fired to high temperatures, they are generally nonreactive at ordinary temperatures. In contrast, crystal transducers must be formed by lapidary techniques from nearly-perfect single crystals. Many of the commonly-used ones are water-soluble; others dehydrate easily when heated.

It is desirable to find ceramic compositions which are suitable for use as electromechanical transducers over a wide temperature interval. To produce such a piezoelectric ceramic, it is necessary that the crystal structure of the material be devoid of a center of symmetry. However, it must also be possible to orient permanently the crystallographic directions of the component grains by an externally applied field.

The prevailing opinion indicates that piezoelectric ceramics can be made only from ferroelectric crystalline materials. These are regarded as ones having a crystal structure which contains a dipole mobile enough to orient itself parallel to its neighbors in adjacent unit cells, and to be reversible by an applied electric field $[1] .^{3}$

In polycrystalline form, the ferroelectric compounds differ in their ability to acquire and retain a piezoelectric effect, even though each would show strong piezoelectricity if a single-domain crystal of it were tested. Barium titanate, widely used as a ceramic transducer, is an example of a ceramic capable of retaining a strong piezoelectric effect. Most of the other ferroelectric compounds, in ceramic form, are inferior. Although there is a steady increase, the number of such known oxide type ferroelectric crystalline compounds is small. Most of these compounds are known to have a distorted perovskite

1 The work covered by this report was sponsored by the Office of Ordnance Research, Department of the Army.

2 Present address, The Brush Laboratories Co., Cleveland, Ohio.

Figures in brackets indicate the literature references at the end of this paper. type structure, $\mathrm{ABO}_{3}$, in which the $\mathrm{A}$ ions occupy the corners and the $\mathrm{B}$ ions occupy the center position of the unit cell, with the oxygen ions at the center of the faces. The ferroelectric compounds have been found to have either rhombohedral, tetragonal, or orthorhombic symmetry. It is being recognized that studies of solid-solution series between known ferroelectrics and other materials related in structure can yield ceramic transducer materials of promise.

It is known that the piezoelectric properties and the dielectric constant of ferroelectric barium titanate are enhanced at temperatures near those of polymorphic inversions below the Curie temperature, such as near $0^{\circ} \mathrm{C}[2]$. At these inversion temperatures, the crystal form changes from one ferroelectric modification of the perovskite structure to another. More recently, compositional boundaries have been noted between ferroelectric phases of slightly differing structure [3]. An abrupt change in the structure of a solid solution with variation in composition is known as a morphotropic transformation. These morphotropic transformations [4] occur because of free energy differences between two or more alternate crystallographic modifications of a given basic structure type. As one ion replaces another in a solid solution, the energies of the different structures change, and the crystal assumes the structure having the minimum free energy.

One example of morphotropism between ferroelectric phases in solid solution is found in the system $\mathrm{PbZrO}_{3}-\mathrm{PbTiO}_{3}[3,5]$. In this system it was found that the c/a ratio of tetragonal $\mathrm{PbTiO}_{3}$, was decreased as $\mathrm{PbZrO}_{3}$ was added in solid solution until a morphotropic phase boundary occurred at 55 mole percent $\mathrm{PbZrO}_{3}$. Solid solutions higher in $\mathrm{PbZrO}_{3}$ content were rhombohedral. Subsequent experiments by the present investigators $[6,7]$ showed that the room temperature dielectric constant and induced piezoelectric effects of ceramics with compositions in this system were enhanced as the composition approached the phase boundary. 
From a piezoelectric and dielectric standpoint, it would appear that compositional proximity to a morphotropic transformation is even more desirable than temperature proximity to a polymorphic transformation. In consequence, experiments were continued on other solid-solution systems in which morphotropic transformations might be found.

\section{Experimental Procedure}

\subsection{Preparation of Specimens}

The materials used for these investigations included reagent-grade $\mathrm{PbO}$, a high-purity hydrated $\mathrm{SnO}_{2}$, a commercially-pure grade of $\mathrm{ZrO}_{2}$, and a good commercial dielectric grade of $\mathrm{TiO}_{2}$. The $\mathrm{HfO}_{2}$ contained about 0.7 percent by weight of $\mathrm{Fe}_{2} \mathrm{O}_{3}$. It also contained 3.1 weight percent of $\mathrm{TiO}_{2}$, for which allowance was made in computing the batches. Batches intended to yield $25 \mathrm{~g}$ of calcined material were weighed and ball-milled with distilled water for intimate mixing. They were then dried under infrared, mixed again in a mortar and, in most instances, pressed loosely into a pellet and calcined at $800^{\circ} \mathrm{C}$ for $\frac{1}{2} \mathrm{hr}$ in a covered platinum crucible. The calcined pellet was ground thoroughly, and specimens were then pressed at $15,000 \mathrm{lb} / \mathrm{in}^{2}{ }^{2}$ in the form of $1 / 2$-in. disks of 0.050 to $0.100 \mathrm{in}$. thick. A few drops of distilled water were added to prepare the powder for pressing; organic binders were avoided. Compositions which were prepared in the ternary system $\mathrm{PbZrO}_{3}-\mathrm{PbTiO}_{3}-\mathrm{PbO}: \mathrm{SnO}_{2}$ are shown as open circles in figure 1.

The specimens were weighed dry, and heat-treated in a platimum-wound resistance furnace. As Roberts [8] pointed out, the lead oxide in lead zirconate and its solid-solutions is volatile. Its loss can be

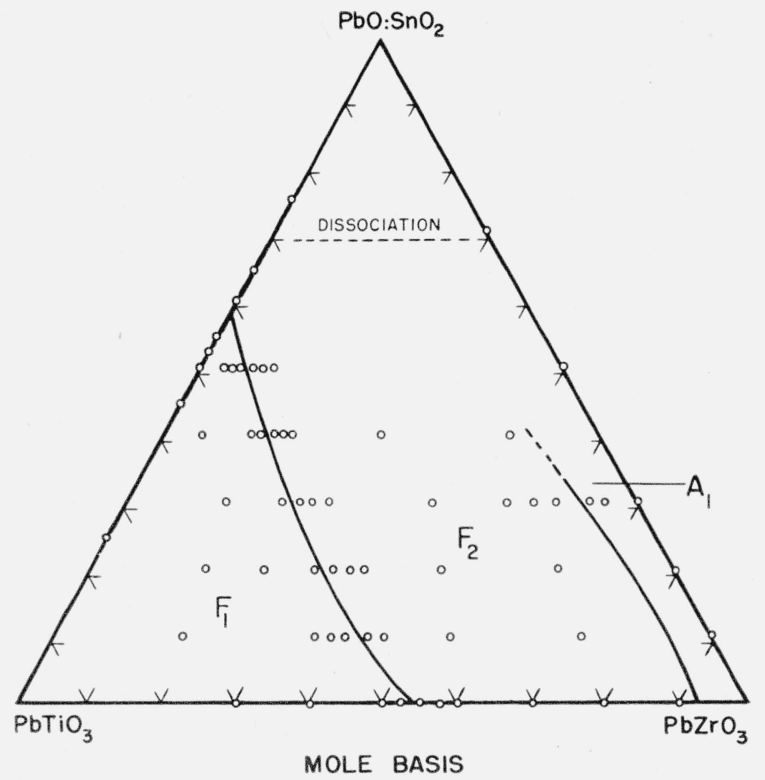

Figure 1. Compositions studied in the ternary system $\mathrm{PbTiO}_{3-}$ $\mathrm{PbZrO}_{3}-\mathrm{PbO}: \mathrm{SnO}_{2}$ and the morphotropic boundaries at $25^{\circ} \mathrm{C}$ for part of this system.

The region near $\mathrm{PbO}: \mathrm{SnO}_{2}$ is characterized by disscciation. $\mathrm{F}_{1}$-ferroelectric, tetragonal; $\mathrm{F}_{2}$-ferroelectric, rhombohedral; $\mathrm{A}_{1}$-antiferroelectric; 0 -compositions studies. controlled by firing the specimens in an atmosphere that contains lead oxide vapor. For this, the specimens were placed in a large $(75 \mathrm{ml})$ platinum crucicible, and separated from one another by platinum foil, as shown in figure 2. A pellet of $\mathrm{PbO}+\mathrm{ZrO}_{2}$, enriched in $\mathrm{PbO}$ over the 1:1 molar ratio by 4 weight percent, was placed on top of the stack of specimens. This pellet provided an "atmosphere" enriched in $\mathrm{PbO}$ vapor to retard evaporation of $\mathrm{PbO}$ from the specimens. A smaller crucible was inverted over the stack of specimens and another "atmosphere" pellet was placed on top of it. The large, or outer crucible, was then covered. It was found to be possible, by varying the weights of these "atmosphere" pellets, to cause the specimens to lose weight, remain unchanged, or gain weight. This procedure follows that of Shelton et al. [9] who used it to produce leadcontaining ceramic dielectric specimens. For the heat treatment, a uniform heating rate of $4 \frac{1 / 2}{}{ }^{\circ} \mathrm{C} / \mathrm{min}$ was maintained up to the soaking temperature. After soaking the specimen for 20 to $60 \mathrm{~min}$, the furnace was allowed to cool naturally. Since the furnace is not massive, the initial cooling was quite rapid.

In general, the weight change of a specimen was less than 2 percent. Specimens with less than 0.1 percent absorption were considered to be matured. All specimens which were thought to have lost too much $\mathrm{PbO}$, or were not well matured, were rejected. Absorption was measured by placing the weighed specimens into a flask, evacuating the air in the flask by means of an aspirator, and then allowing $\mathrm{CCl}_{4}$ to enter the flask and cover the specimens. The specimens remained in the $\mathrm{CCl}_{4}$ for about $3 \mathrm{~min}$. Carbon tetrachloride was selected for this procedure since it allowed a rapid method of measurement. The results were then computed in terms of equivalent water absorption.

In addition to the absorption, the linear shrinkage and the apparent density were measured as indications of maturity. The linear shrinkage was obtained by comparing the diameter of the disk-shaped specimens before and after heat treatment. The apparent density was obtained by calculation from the diameter and thickness of the specimens and their fired weight. The values, because of slight warping and eccentricity, are accurate to about 2 percent and are suitable for comparison purposes. The values of heat treatment and ceramic properties of the compositions studies are listed in table 1.

As desired, X-ray diffraction patterns were obtained with a Geiger-counter type X-ray diffractometer using $\mathrm{Cu}_{\mathrm{K}_{\alpha}}$ radiation. These tests were generally made on intact ceramic specimens, although, in a few instances when orientation difficulties were suspected, powder samples were used. However, it was preferred to use specimens intact so that the same specimen would serve for other tests. From the lattice parameters, and the molecular weight of the solid solution based on its nominal composition, the theoretical density was computed. After the X-ray measurements, silver paste was applied to the disk faces and then fired on to form electrodes. 
TABLE 1. Batch composition, heat treatment and ceramic properties of designated solid solutions

\begin{tabular}{|c|c|c|c|c|c|c|c|c|c|c|}
\hline \multirow{2}{*}{ Number } & \multicolumn{4}{|c|}{ Batch composition } & \multicolumn{2}{|c|}{ Heat treatment } & \multirow{2}{*}{$\begin{array}{l}\text { Equiv- } \\
\text { alent } \\
\text { water } \\
\text { absorption }\end{array}$} & \multirow{2}{*}{ Shrinkage } & \multirow{2}{*}{$\begin{array}{c}\text { Apparent } \\
\text { density }\end{array}$} & \multirow{2}{*}{$\begin{array}{l}\text { Theoret- } \\
\text { ical } \\
\text { density }\end{array}$} \\
\hline & $\mathrm{PbZrO}_{3}$ & $\mathrm{PbTiO}_{3}$ & $\mathrm{PbO}: \mathrm{SnO}_{2}$ & $\mathrm{PbHfO}_{3}$ & Temperature & Time & & & & \\
\hline $\begin{array}{r}1 \\
2 \\
3 \\
4 \\
5 \\
6 \\
7 \\
8 \\
9 \\
10\end{array}$ & $\begin{array}{l}\text { mole \% } \\
30 \\
40 \\
50 \\
52.5 \\
55 \\
57.5 \\
60 \\
70 \\
80 \\
90\end{array}$ & $\begin{array}{l}\text { mole } \% \\
70 \\
60 \\
50 \\
47.5 \\
45 \\
42.5 \\
40 \\
30 \\
20 \\
10\end{array}$ & $\begin{array}{c}\text { mole \% } \\
\\
\\
\end{array}$ & $\begin{array}{c}\text { mole \% } \\
- \\
- \\
-\end{array}$ & 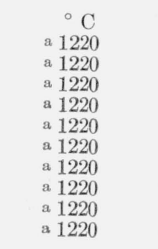 & $\begin{array}{l}\min \\
30 \\
30 \\
30 \\
30 \\
30 \\
30 \\
30 \\
30 \\
30 \\
30\end{array}$ & $\begin{array}{l}\% \\
0.02 \\
.00 \\
.00 \\
.00 \\
.00 \\
.00 \\
.00 \\
.00 \\
.00\end{array}$ & $\begin{array}{l}\% \\
19 \\
17 \\
15 \\
15 \\
15 \\
14 \\
14 \\
14 \\
13 \\
13\end{array}$ & $\begin{array}{l}\mathrm{kg} / \mathrm{m}^{3} \\
7.3 \\
7.3 \\
7.1 \\
7.2 \\
7.2 \\
7.2 \\
7.3 \\
7.5 \\
7.4 \\
7.2\end{array}$ & $\begin{array}{l}\mathrm{kg} / \mathrm{m}^{3} \\
8.0 \\
8.0 \\
8.0 \\
8.0 \\
8.0 \\
8.0 \\
8.0 \\
8.0 \\
8.0 \\
8.0\end{array}$ \\
\hline $\begin{array}{l}11 \\
12 \\
13 \\
14 \\
15 \\
16 \\
17 \\
18\end{array}$ & 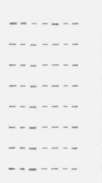 & $\begin{array}{l}75 \\
55 \\
50 \\
47.5 \\
45 \\
40 \\
35 \\
25\end{array}$ & $\begin{array}{l}25 \\
45 \\
50 \\
52.5 \\
55 \\
60 \\
65 \\
75\end{array}$ & 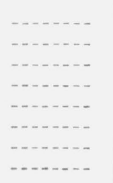 & $\begin{array}{r}\text { a } 1100 \\
1175 \\
1150 \\
1150 \\
1150 \\
1150 \\
1150 \\
\text { a } 1100\end{array}$ & $\begin{array}{l}60 \\
30 \\
30 \\
30 \\
30 \\
30 \\
30 \\
60\end{array}$ & $\begin{array}{l}.00 \\
.00 \\
.03 \\
.02 \\
.03 \\
.06 \\
.09 \\
.00\end{array}$ & $\begin{array}{l}19 \\
16 \\
16 \\
17 \\
17 \\
18 \\
17 \\
22\end{array}$ & $\begin{array}{l}7.7 \\
7.9 \\
8.0 \\
8.2 \\
8.0 \\
8.2 \\
7.6 \\
7.6\end{array}$ & $\begin{array}{l}8.3 \\
8.7 \\
8.7 \\
8.7 \\
8.7 \\
8.8 \\
8.9 \\
9.0\end{array}$ \\
\hline $\begin{array}{l}19 \\
20 \\
21 \\
22 \\
23\end{array}$ & $\begin{array}{l}90 \\
80 \\
70 \\
50 \\
30\end{array}$ & מ & $\begin{array}{l}10 \\
20 \\
30 \\
50 \\
70\end{array}$ & 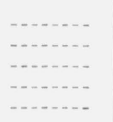 & $\begin{array}{l}1225 \\
1210 \\
1250 \\
1300 \\
1225\end{array}$ & $\begin{array}{l}60 \\
30 \\
20 \\
60 \\
60\end{array}$ & $\begin{array}{l}.14 \\
.05 \\
.41 \\
.00 \\
.20\end{array}$ & $\begin{array}{l}13 \\
11 \\
14 \\
19 \\
21\end{array}$ & $\begin{array}{l}7.4 \\
7.4 \\
7.5 \\
7.9 \\
7.8\end{array}$ & $\begin{array}{l}8.2 \\
8.3 \\
8.5 \\
8.7 \\
8.9\end{array}$ \\
\hline $\begin{array}{l}24 \\
25 \\
26 \\
27 \\
28 \\
29 \\
30 \\
31\end{array}$ & $\begin{array}{l}18 \\
36 \\
38.25 \\
40.5 \\
42.75 \\
45 \\
54 \\
72\end{array}$ & $\begin{array}{l}72 \\
54 \\
51.75 \\
49.5 \\
47.25 \\
45 \\
36 \\
18\end{array}$ & $\begin{array}{l}10 \\
10 \\
10 \\
10 \\
10 \\
10 \\
10 \\
10\end{array}$ & 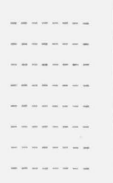 & $\begin{array}{l}1230 \\
1250 \\
1250 \\
1250 \\
1250 \\
1250 \\
1250 \\
1250\end{array}$ & $\begin{array}{l}30 \\
30 \\
30 \\
30 \\
30 \\
30 \\
30 \\
30\end{array}$ & $\begin{array}{l}.00 \\
.03 \\
.01 \\
.00 \\
.04 \\
.00 \\
.02 \\
.00\end{array}$ & $\begin{array}{l}13 \\
13 \\
14 \\
14 \\
14 \\
14 \\
13 \\
14\end{array}$ & $\begin{array}{l}7.3 \\
7.0 \\
7.2 \\
7.2 \\
7.6 \\
7.6 \\
7.6 \\
7.5\end{array}$ & $\begin{array}{l}8.2 \\
8.1 \\
8.2 \\
8.2 \\
8.2 \\
8.1 \\
8.2 \\
8.1\end{array}$ \\
\hline $\begin{array}{l}32 \\
33 \\
34 \\
35 \\
36 \\
37 \\
38 \\
39\end{array}$ & $\begin{array}{l}16 \\
24 \\
32 \\
34 \\
36 \\
38 \\
48 \\
64\end{array}$ & $\begin{array}{l}64 \\
56 \\
48 \\
46 \\
44 \\
42 \\
32 \\
16\end{array}$ & $\begin{array}{l}20 \\
20 \\
20 \\
20 \\
20 \\
20 \\
20 \\
20\end{array}$ & 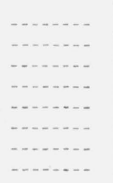 & $\begin{array}{l}1230 \\
1250 \\
1250 \\
1250 \\
1250 \\
1250 \\
1250 \\
1270\end{array}$ & $\begin{array}{l}30 \\
30 \\
30 \\
30 \\
30 \\
30 \\
30 \\
30\end{array}$ & $\begin{array}{l}.00 \\
.01 \\
.00 \\
.00 \\
.00 \\
.01 \\
.00 \\
.03\end{array}$ & $\begin{array}{l}14 \\
14 \\
13 \\
13 \\
14 \\
14 \\
14 \\
15\end{array}$ & $\begin{array}{l}7.5 \\
7.5 \\
7.7 \\
7.7 \\
7.7 \\
7.8 \\
7.9 \\
7.6\end{array}$ & $\begin{array}{l}8.3 \\
8.3 \\
8.3 \\
8.3 \\
8.3 \\
8.3 \\
8.2 \\
8.3\end{array}$ \\
\hline $\begin{array}{l}40 \\
41 \\
42 \\
43 \\
44 \\
45 \\
46 \\
47 \\
48 \\
49 \\
50\end{array}$ & $\begin{array}{l}14 \\
22.75 \\
24.5 \\
26.25 \\
28 \\
42 \\
52.5 \\
56 \\
59.5 \\
63 \\
66.5\end{array}$ & $\begin{array}{l}56 \\
47.25 \\
45.5 \\
43.75 \\
42 \\
28 \\
17.5 \\
14 \\
10.5 \\
7 \\
3.5\end{array}$ & $\begin{array}{l}30 \\
30 \\
30 \\
30 \\
30 \\
30 \\
30 \\
30 \\
30 \\
30 \\
30\end{array}$ & 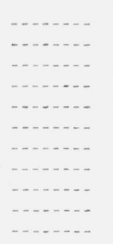 & $\begin{array}{l}1250 \\
1250 \\
1250 \\
1250 \\
1250 \\
1250 \\
1250 \\
1275 \\
1250 \\
1250 \\
1250\end{array}$ & $\begin{array}{l}30 \\
30 \\
30 \\
30 \\
30 \\
30 \\
30 \\
30 \\
20 \\
20 \\
20\end{array}$ & $\begin{array}{l}.02 \\
.01 \\
.00 \\
.00 \\
.00 \\
.01 \\
.06 \\
.04 \\
.31 \\
.42 \\
.14\end{array}$ & $\begin{array}{l}14 \\
15 \\
14 \\
15 \\
14 \\
14 \\
14 \\
13 \\
13 \\
13 \\
14\end{array}$ & $\begin{array}{l}7.6 \\
7.8 \\
7.8 \\
7.8 \\
7.8 \\
7.8 \\
7.6 \\
7.6 \\
7.6 \\
7.5 \\
7.7\end{array}$ & $\begin{array}{l}8.5 \\
8.3 \\
8.5 \\
8.4 \\
8.4 \\
8.4 \\
8.4 \\
8.4 \\
8.4 \\
8.4 \\
8.5\end{array}$ \\
\hline $\begin{array}{l}51 \\
52 \\
53 \\
54 \\
55 \\
56 \\
57 \\
58\end{array}$ & $\begin{array}{l}6 \\
12 \\
13.5 \\
15 \\
16.5 \\
18 \\
30 \\
48\end{array}$ & $\begin{array}{l}54 \\
48 \\
46.5 \\
45 \\
43.5 \\
42 \\
30 \\
12\end{array}$ & $\begin{array}{l}40 \\
40 \\
40 \\
40 \\
40 \\
40 \\
40 \\
40\end{array}$ & 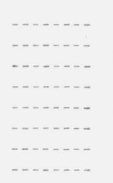 & $\begin{array}{c}1250 / 1225 / 1200 \\
1250 / 1225 / 1200 \\
1250 / 1225 / 1200 \\
1240 / 1225 \\
1240 / 1225 \\
1240 / 1225 \\
1250 \\
1240\end{array}$ & $\begin{array}{l}\text { b } 60-60-60 \\
\text { b } 60-60-60 \\
\text { b } 60-60-60 \\
\text { b } 60-60 \\
\text { b } 60-60 \\
\text { b } 60-60 \\
\quad 30 \\
\quad 60\end{array}$ & $\begin{array}{l}.40 \\
.09 \\
.05 \\
.11 \\
.03 \\
.07 \\
.05 \\
.03\end{array}$ & $\begin{array}{l}15 \\
14 \\
14 \\
14 \\
14 \\
15 \\
15 \\
15\end{array}$ & $\begin{array}{l}7.2 \\
7.6 \\
7.6 \\
7.8 \\
7.8 \\
7.8 \\
7.9 \\
7.9\end{array}$ & $\begin{array}{l}8.6 \\
8.6 \\
8.6 \\
8.6 \\
8.6 \\
8.6 \\
8.6 \\
8.5\end{array}$ \\
\hline $\begin{array}{l}59 \\
60 \\
61 \\
62 \\
63 \\
64\end{array}$ & $\begin{array}{c}3.75 \\
5 \\
6.25 \\
7.50 \\
8.75 \\
10\end{array}$ & $\begin{array}{l}46.25 \\
45 \\
43.75 \\
42.5 \\
41.25 \\
40\end{array}$ & $\begin{array}{l}50 \\
50 \\
50 \\
50 \\
50 \\
50\end{array}$ & $\begin{array}{c} \\
\cdots\end{array}$ & $\begin{array}{l}1125 \\
1125 \\
1125 \\
1125 \\
1125 \\
1160\end{array}$ & $\begin{array}{l}30 \\
30 \\
30 \\
30 \\
30 \\
30\end{array}$ & $\begin{array}{l}1.04 \\
0.97 \\
1.01 \\
0.94 \\
1.02 \\
0.82\end{array}$ & $\begin{array}{l}13 \\
14 \\
14 \\
14 \\
14 \\
14\end{array}$ & $\begin{array}{l}7.6 \\
7.6 \\
7.6 \\
7.7 \\
7.7 \\
7.6\end{array}$ & $\begin{array}{l}8.3 \\
8.3 \\
8.2 \\
8.3 \\
8.3 \\
8.3\end{array}$ \\
\hline $\begin{array}{l}65 \\
66 \\
67 \\
68 \\
69 \\
70 \\
71 \\
72 \\
73 \\
74 \\
75 \\
76\end{array}$ & 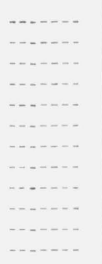 & $\begin{array}{l}90 \\
70 \\
60 \\
55 \\
52.5 \\
50 \\
47.25 \\
45 \\
42.5 \\
40 \\
30 \\
10\end{array}$ & 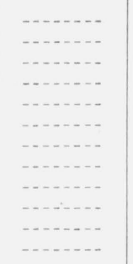 & $\begin{array}{l}10 \\
30 \\
40 \\
45 \\
47.5 \\
50 \\
52.5 \\
55 \\
57.5 \\
60 \\
70 \\
90\end{array}$ & $\begin{array}{c}1250 \\
1300 \\
1300 \\
1300 \\
1300 \\
1300 \\
1300 \\
1300 \\
1300 \\
1325 / 1300 \\
1325 / 1300 \\
1325 / 1300\end{array}$ & $\begin{array}{l}30 \\
60 \\
60 \\
60 \\
60 \\
60 \\
60 \\
60 \\
60 \\
\text { b } 60-60 \\
\text { b } 60-60 \\
\text { b } 60-60\end{array}$ & $\begin{array}{l}2.8 \\
1.3 \\
0.00 \\
.00 \\
.00 \\
.02 \\
.00 \\
.01 \\
.02 \\
.03 \\
.09 \\
.41\end{array}$ & $\begin{array}{r}8 \\
8 \\
8 \\
9 \\
10 \\
9 \\
10 \\
10 \\
9 \\
8 \\
8 \\
9\end{array}$ & $\begin{array}{l}6.6 \\
7.4 \\
8.1 \\
8.3 \\
8.5 \\
8.4 \\
8.6 \\
8.6 \\
8.7 \\
8.4 \\
8.3 \\
8.8\end{array}$ & $\begin{array}{r}8.3 \\
8.8 \\
9.0 \\
9.1 \\
9.2 \\
9.2 \\
9.3 \\
9.3 \\
9.4 \\
9.5 \\
9.7 \\
10.1\end{array}$ \\
\hline
\end{tabular}

a Not calcined. All others calcined at $800^{\circ} \mathrm{C}$ for $30 \mathrm{~min}$.

b Indicates repeated heat treatment of same sample. 


\subsection{Dielectric Measurements}

At least $24 \mathrm{hr}$ after the specimens were silvered, measurements were made of the dielectric constant and dissipation factor at $25^{\circ} \mathrm{C}$, with less than 40 -percent relative humidity. The measurements were made at frequencies of $1 \mathrm{kc}, 50 \mathrm{kc}, 1 \mathrm{Mc}$, and $20 \mathrm{Mc}$. The $1 \mathrm{kc}$ measurement was made with a capacitance bridge; at the other frequencies, a Q-meter was used. To show the variation of dielectric constant and dissipation factor with temperature, measurements were made from $-50^{\circ} \mathrm{C}$ through the Curie temperature, at a frequency of $1 \mathrm{Mc}$. From $-50^{\circ} \mathrm{C}$ to $25^{\circ} \mathrm{C}$ a twin- $\mathrm{T}$ impedance measuring circuit was used on the specimens which were contained in a refrigerated cabinet maintained at the desired temperature. A Q-meter was used for the temperature range from $25^{\circ} \mathrm{C}$ to the Curie temperature, which was as high as $420^{\circ} \mathrm{C}$ in one instance. The specimens were kept on a silver slab, the temperature of which was raised approximately $4^{\circ} \mathrm{C}$ per minute. As each desired temperature was reached, a measurement was made. Temperature was measured by means of a chromel-alumel thermocouple imbedded in a control specimen resting next to the test specimen. These measurements were then plotted as a function of temperature. Any irregularities which might be found in such curves would be indicative of polymorphic transformations.

\subsection{Polarization}

After dielectric measurements were completed, the specimens were polarized by subjecting them to strong d-c fields. The specimens were kept immersed in a dielectric medium of clean carbon tetrachloride at room temperature. Generally, it was desired to maintain a voltage gradient of 150 $\mathrm{v} / \mathrm{mil}$ (or $150 \mathrm{kv} / \mathrm{in}$.) for $1 \mathrm{hr}$. For some compositions, this could not be done. Even though attempts were made on several such specimens, excessive sparking or electrical leakage occurred. In these instances, piezoelectric data for less intense fields were reported.

\subsection{Piezoelectric Measurements}

The chief figure of merit used to evaluate the piezoelectric properties of the ceramic disks was the radial couping coefficient. This was tested one week after polarization by measuring the resonance and antiresonance frequencies of the radial fundamental mode of vibration of a given specimen. A scheme essentially similar to the one described by Mason $[10$, p. 292] was used, although the d-c bias shown was not employed. Frequency was measured by the dial calibration of a signal generator. When desired, this was checked with a calibrated frequency meter. The following equation, adapted from Mason [10], was used:

$$
\frac{k_{r}^{2}}{1-k_{r}^{2}}=2.51 \frac{f_{a}-f_{r}}{f_{r}}
$$

where $k_{r}=$ radial couping coefficient $f_{n}=$ radial antiresonance frequency $f_{r}=$ radial resonance frequency

The piezoelectric properties were evaluated further for specimens having their composition close to one of the morphotropic boundaries between ferroelectric phases. Measurements were made of the radial resonance and antiresonance frequencies and of the $1 \mathrm{kc}$ dielectric constants at a series of elevated temperatures below the Curie point. From these, the frequency constant (the product of the disk radius and the radial resonance frequency) and the $d_{31}$ and $g_{31}$ piezoelectric constants were computed, as well as the radial couping coefficient at each temperature. For this measurement, the specimen was placed on a hot plate which was heated slowly through the desired temperature interval. Temperature was measured with a chromel-alumel thermocouple embedded in a control specimen next to the one being tested.

The coupling coefficient squared indicates the ability to transform electrical energy to mechanical energy, or, conversely, to transform mechanical energy to electrical. The $d$ constant indicates the charge produced by a unit force or the deformation produced by a given potential. The $g$ constant indicates the potential gradient (open circuit) caused by a given stress, or conversely, the strain produced by a given charge density. The first subscript 3 refers to an electrical field in the direction of polarization. For a disk, this is usually parallel to the direction of thickness. The second subscript 1 refers to a strain normal to the polarization direction, alined with any disk radius.

At room temperature, in addition to the formula noted for coupling coefficient, the following expressions, adapted from Mason [10], were used:

$$
d_{31}=k_{r} \sqrt{\frac{(1-\sigma) \epsilon_{0} \epsilon^{T}}{2 Y_{0}^{E}}}
$$

where $d_{31}=$ transverse piezoelectric constant, coulombs

$$
\text { newton }
$$

$\sigma=$ Poisson's ratio, taken as 0.3

$\epsilon_{0}=$ permittivity of vacuum

$=8.85 \times 10^{-12}$ farads/meter

$\epsilon^{T}=$ relative dielectric constant at temperature $T\left(25^{\circ} \mathrm{C}\right)$ and at a frequency below all resonances $(1 \mathrm{kc})$.

$\mathrm{Y}_{0}^{E}=$ elastic modulus, $\frac{\text { newtons }}{\text { meter }^{2}}$ evaluated as follows:

$$
Y_{0}^{E}=\left[\frac{2 \pi a f_{r}}{2.03}\right]^{2}\left[\rho\left(1-\sigma^{2}\right)\right]
$$

where $a=$ disk radius, meters

$$
\rho=\text { density, } \frac{\text { kilograms }}{\text { meter }^{3}}
$$


also

$$
g_{31}=\frac{d_{31}}{\epsilon_{0} \epsilon^{T}}
$$

where $g_{31}=$ transverse piezoelectric constant, $\frac{\text { meter volts }}{\text { newton }}$

To evaluate the $d_{31}$ and $g_{31}$ constants at the elevated temperature, the following expressions were used:

$$
d_{31}^{B}=d_{31}^{A} \frac{k_{r}^{B}}{k_{r}^{A}} \frac{f_{r}^{A}}{f_{r}^{B}} \sqrt{\frac{\epsilon^{T^{B}}}{\epsilon^{T^{A}}}}
$$

where superscript $A$ denotes room temperature and superscript $B$ refers to the elevated temperature

and

$$
g_{31}^{B}=\frac{d_{31}^{B}}{\epsilon_{0} \epsilon^{T^{B}}} .
$$

This method takes changes in elasticity into account by means of the frequency ratio. It ignores only the small variations in density and the changes, if any, in Poisson's ratio.

At each of the elevated temperatures, the radial coupling coefficient and the frequency constant were calculated separately from the measured values.

\subsection{Choice of Reported Values}

A series of heat treatments yielded specimens with varying absorption, fired density, and degree of mechanical perfection. It was clear that maximum density and minimum absorption yielded the highest values, particularly of radial coupling coefficient, provided that cracks or inclusions were absent. The values reported for the measured properties were taken from an individual specimen thought most nearly to approximate the ideal value of the properties of the material under consideration. For each composition, 1 to 10 matured specimens were measured. For the compositions close to a morphotropic phase boundary, a larger number of specimens of each was tested. In those compositions where maturity was not attained, the values reported are those for the specimens with the lowest absorption.

Inasmuch as no specimen was perfect in every respect, it was felt that the specimen with the highest coupling coefficient would also have a dielectric constant that most nearly approached the ideal value for the composition. Systematic variation of composition indicated that choices of this kind were justified.

\section{Results and Discussion}

\subsection{Properties of Lead Components}

$$
\text { a. } \mathrm{PbTiO}_{3}
$$

Lead titanate is a ferroelectric perovskite, isomorphous with barium titanate (tetragonal, $\mathrm{c} / \mathrm{a}>1$ ) [11]. Its Curie temperature is near $490^{\circ} \mathrm{C}$, and there are no lower polymorphic phase transformations, such as characterize barium titanate. At room temperature, its tetragonal c/a ratio is 1.06 , which represents a relatively large distortion from the ideal cubic perovskite structure. Lead titanate was known long before its interesting dielectric properties were realized [11, 12, 13]. Given sufficient time, the compound forms completely at temperatures as low as $375^{\circ} \mathrm{C}[13]$.

Since $\mathrm{PbTiO}_{3}$ is ferroelectric, oriented single crystals of it should display a strong piezoelectric effect. However, in ceramic form, specimens of $\mathrm{PbTiO}_{3}$ frequently break after cooling through the Curie temperature [14]. Experiments with solid solutions rich in $\mathrm{PbTiO}_{3}$ indicate that room-temperature polarization by attainable $d$-c fields leaves no perceptible piezoelectric effect, presumably because the $\mathrm{c} / \mathrm{a}$ ratio is so large that reorientation of the domains would necessitate excessive deformations and stresses at the grain boundaries. Polarization at elevated temperatures near the Curie point would be difficult because of conductivity.

\section{b. $\mathrm{PbZrO}_{3}$}

Although $\mathrm{PbZrO}_{3}$ has been known for some time [15], its unusual dielectric properties [16] were noticed only a few years ago. Lead zirconate is considered to be antiferroelectric, and thus will not form a piezoelectric ceramic $[17,18,19]$. Its $\mathrm{X}$-ray powder pattern, at first approximation, is that of a tetragonal perovskite with $\mathrm{c} / \mathrm{a}<1$ [20]. It has since been recognized [18] that, although the primitive cell does have this structure, the larger true unit cell is of orthorhombic symmetry with an antiparallel arrangement of dipoles. This antiparallel shift causes the antiferroelectric properties. It also results in superstructure lines in the diffraction pattern.

There is a ferroelectric phase that is close in energy to the antiferroelectric phase at temperatures just below the Curie point [17]. As a result, a plot of dielectric constant as a function of temperature resembles that of a typical ferroelectric. However, the dielectric hysteresis loops which typify a ferroelectric are absent.

\section{c. $\mathrm{PbO}: \mathrm{SnO}_{2}$}

There is some question about the stability of a perovskite-type 1:1 compound of $\mathrm{PbO}$ and $\mathrm{SnO}_{2}$, and even about its existence. Coffeen [21] has reported the properties of a lead stannate precipitated from solution as the di-hydrate. When dehydrated, this material has an X-ray pattern which we consider to be that of a distorted fluorite type structure. It seems possible that this phase, instead of $\mathrm{ABO}_{3}$, may have the formula-type $\mathrm{ABO}_{4}$ like other fluorites. Naray-Szabo [22] reported a tetragonal perovskite structure differing from that of Coffeen's dehydrated material. We have not observed this perovskite. The fluorite-type phase sometimes appears as a diluent in perovskite-type solid solutions rich in $\mathrm{PbO}: \mathrm{SnO}_{2}$. However, a sample of the fluorite-type material that was heated in air to $850^{\circ} \mathrm{C}$ was found 
to be partially decomposed into free $\mathrm{SnO}_{2}$ and an unknown phase. Byström [23] heated $\mathrm{PbCO}_{3}$ and $\mathrm{SnO}_{2}$ in air at $700^{\circ} \mathrm{C}$ for several hours. He found only free $\mathrm{SnO}_{2}$ and the compound $\mathrm{Pb}_{2} \mathrm{SnO}_{4}$. It seems probable that our unknown decomposition phase was identical with this $\mathrm{Pb}_{2} \mathrm{SnO}_{4}$.

Although a perovskite-type $\mathrm{PbSnO}_{3}$ may or may not be stable, solid solutions can be made containing as much as 70 mole percent $\mathrm{PbO}: \mathrm{SnO}_{2}$ in solid solution with another perovskite end member.

\section{d. $\mathrm{PbHfO}_{3}$}

Shirane and Pepinsky [24] reported on $\mathrm{PbHfO}_{3}$. At room temperature it is antiferroelectric, and isomorphous with $\mathrm{PbZrO}_{3}$. However, at $158^{\circ} \mathrm{C}$, another slightly altered antiferroelectric phase appears and persists up to the Curie temperature, $215^{\circ} \mathrm{C}$, where the material becomes cubic and thus paraelectric. Shirane and Pepinsky were able to obtain these structural and dielectric data, even though their total supply of $\mathrm{HfO}_{2}$ was only a single gram. They were troubled by volatilization of $\mathrm{PbO}$ because not enough $\mathrm{HfO}_{2}$ was available to work out a satisfactory firing procedure.

\subsection{Properties of Solid Solutions}

Table 1 gives the compositions, heat treatment, and ceramic properties of the specimens studied. X-ray diffraction powder patterns have provided the lattice parameters shown in table 2 . The dielectric properties at room temperature, the Curie temperature, and the peak dielectric constant for the solid solutions studied are given in table 3 . Table 4 shows the radial coupling coefficient observed for these specimens.

\section{a. $\mathrm{PbTiO}_{3}-\mathrm{PbZrO}_{3}$}

The work on ceramics having compositions in this system has been described briefly elsewhere [7]. However, it will be reviewed here in more comprehensive form.

As mentioned in the introduction, the properties of $\mathrm{Pb}(\mathrm{Zr}, \mathrm{Ti}) \mathrm{O}_{3}$ solid solutions were described by Shirane and Suzuki [4], and later reviewed by Sawaguchi [5]. Although $\mathrm{PbZrO}_{3}$ is antiferroelectric, its solid solutions with more than about 10 mole percent $\mathrm{PbTiO}_{3}$ are ferroelectric, as shown in figure 3a. A morphotropic phase boundary occurs near 55 mole percent $\mathrm{PbZrO}_{3}$. Solid solutions richer in $\mathrm{PbZrO}_{3}$ are rhombohedral (pseudocubic with slight extension along a body diagonal), while those richer in $\mathrm{PbTiO}_{3}$ are tetragonal with $\mathrm{c} / \mathrm{a}>1$ (pseudocubic with slight elongation along one coordinate axis). The deviations from cubic symmetry for these solid solutions are shown in figure $3 \mathrm{~b}$.

Ceramic specimens of these ferroelectrics were found to have structures which confirmed those reported by Shirane. The structures of the compositions studied in this binary system are among those listed in table 2. Although substitution of $\mathrm{Zr}^{4+}$ for $\mathrm{Ti}^{4+}$ in $\mathrm{PbTiO}_{3}$ caused the Curie temperature of the solid solutions to diminish without discontinuity,
TABLE 2. Lattice parameters of designated solid-solution perovskites

\begin{tabular}{|c|c|c|c|c|c|c|}
\hline \multicolumn{3}{|c|}{ Tetragonal } & \multicolumn{2}{|c|}{ Rhombohedral } & \multirow{2}{*}{$\begin{array}{c}\text { Pseudo- } \\
\text { cubic } \\
\text { a }\end{array}$} & \multirow{2}{*}{ Number a } \\
\hline a & $\mathrm{c}$ & $\mathrm{c} / \mathrm{a}$ & a & $\alpha$ & & \\
\hline$A$ & $A$ & & $A$ & & A & \\
\hline 3. 9805 & 4. 1442 & 1. 0411 & $-\ldots$ & - & $\ldots$ & 1 \\
\hline 4. 0045 & 4. 1421 & 1. 0344 & (n) & (n) & ...... & 2 \\
\hline 4. 0311 & 4. 1393 & 1. 0268 & -..... & . & & 3 \\
\hline 4. 0448 & 4. 1383 & 1. 0231 & - & & 烈 & 4 \\
\hline 4. 0838 & 4. 1054 & 1. 0053 & 4. 0817 & $89.79^{\circ}$ & 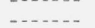 & b 5 \\
\hline$\ldots$ & - - & - n... & 4. 0827 & 89. $69^{\circ}$ & -. & 6 \\
\hline ..... & - n... & - n & 4. 0818 & 89. $76^{\circ}$ & $\ldots$ & 7 \\
\hline - . . & - n... & - n. & 4. 1059 & $89.74^{\circ}$ & & 8 \\
\hline (n... & - & - & 4. 1236 & $89.75^{\circ}$ & - n & 9 \\
\hline (n) & - & (n) & 4. 1385 & $89.73^{\circ}$ & - & 10 \\
\hline 3. 956 & 4. 095 & 1. 035 & & & & 11 \\
\hline 3.975 & 4. 064 & 1. 022 & ....... & . & ......... & 12 \\
\hline 3. 984 & 4.060 & 1.018 & ....... & ...... & & 13 \\
\hline 3. 993 & 4. 051 & 1.015 & (n) & (n) & - & 14 \\
\hline 4. 007 & 4. 047 & 1. 010 & (n) & (n) & & $\begin{array}{l}14 \\
15\end{array}$ \\
\hline$\ldots$ & - n & - n & -..... & ..... & 4. 023 & 16 \\
\hline - n... & $\ldots$ & -..... & (...... & ...... & 4. 026 & 17 \\
\hline$\ldots$ & -...... & - & -..... & -....- & 4. 036 & c 18 \\
\hline 4. 146 & 4. 106 & 0.991 & & & & d 19 \\
\hline 4. 137 & 4. 094 & .990 & - & - & - & d 20 \\
\hline 4. 125 & 4. 090 & .992 & - & . & - & d 21 \\
\hline 4. 103 & 4. 077 & .993 & - & - & - & d 22 \\
\hline 4. 097 & 4. 072 & .994 & - & - & - & d 23 \\
\hline 3. 962 & 4. 117 & 1. 039 & -....... & ....... & -- & 24 \\
\hline 4. 019 & 4. 128 & 1. 027 & -.... & ..... & 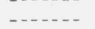 & 25 \\
\hline 4. 017 & 4. 116 & 1.005 & - & - & -...... & 26 \\
\hline 4. 015 & 4. 108 & 1.023 & & & & 27 \\
\hline 4. 055 & 4. 115 & 1. 015 & 4. 055 & $89.78^{\circ}$ & - & e 28 \\
\hline -... & - . - & - . & 4. 067 & $89.80^{\circ}$ & $\ldots$ & 29 \\
\hline -.... & -..... & -.... & 4. 074 & $89.76^{\circ}$ & - & 30 \\
\hline - . - & ....... & ...... & 4. 116 & $89.74^{\circ}$ & ........ & 31 \\
\hline 3. 979 & 4. 099 & 1. 030 & - n..... & -....- & & 32 \\
\hline 4. 002 & 4. 103 & 1.025 & - & . & 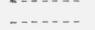 & 33 \\
\hline 4. 024 & 4. 097 & 1. 018 & & & - & 34 \\
\hline - . . . & ....... & ....... & 4. 046 & $89.80^{\circ}$ & ... & 35 \\
\hline$\ldots$ & ..... & ..... & 4. 053 & $89.78^{\circ}$ & $\cdots$ & 36 \\
\hline .... & -..... & - . & 4. 056 & $89.78^{\circ}$ & $\ldots$ & 37 \\
\hline$\ldots$ & .... & . & 4. 089 & $89.78^{\circ}$ & 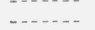 & 38 \\
\hline - . . - & - . & -..... & 4. 103 & $89.84^{\circ}$ & ........ & 39 \\
\hline 3. 988 & 4. 082 & 1. 024 & & - n. & & 40 \\
\hline 4. 082 & 4. 015 & 1.016 & - & - & & 41 \\
\hline - . - & - ..... & - n. & & & 4. 034 & ${ }^{f} 42$ \\
\hline$\ldots$ & - & - n. & 4. 044 & $89.80^{\circ}$ & $\ldots$ & 43 \\
\hline$\ldots$ & -..... & - & 4. 057 & $89.82^{\circ}$ & - & 44 \\
\hline - . . . & - n. & - . & 4. 071 & $89.84^{\circ}$ & $\ldots$ & 45 \\
\hline$\ldots$ & -..... & - & 4. 090 & $89.87^{\circ}$ & - & 46 \\
\hline -...- & - & - & 4. 099 & $89.88^{\circ}$ & - & 47 \\
\hline$\ldots$. & ..... & - & 4. 106 & $89.88^{\circ}$ & - & 48 \\
\hline 4. 114 & 4. 084 & 0.993 & ........ & -..... & - & d 49 \\
\hline 4. 119 & 4. 087 & .992 & - & . & - & d 50 \\
\hline 3. 979 & 4. 064 & 1. 021 & -..... & ....... & -- & 51 \\
\hline 4. 004 & 4. 065 & 1.015 & ...... & ...... & ....... & 52 \\
\hline 4. 008 & 4. 064 & 1. 014 & & & - & в 53 \\
\hline$\ldots$ & - - & -... & 4. 026 & $89.82^{\circ}$ & $\ldots \ldots$ & e 54 \\
\hline - . . . & -...... & -...... & 4. 034 & $89.78^{\circ}$ & -......... & e 55 \\
\hline$\ldots$ & -.... & ....... & 4. 036 & $89.82^{\circ}$ & ........ & 56 \\
\hline$\ldots \ldots$ & - . - & - & 4. 059 & $89.88^{\circ}$ & $\ldots \ldots$ & 57 \\
\hline - & - & - & 4. 091 & $89.90^{\circ}$ & ....... & 58 \\
\hline 3. 989 & 4. 061 & 1. 018 & -...... & - - & .... & 59 \\
\hline 3. 998 & 4. 064 & 1. 016 & - & ..... & $\ldots$. & 60 \\
\hline 4. 010 & 4. 070 & 1.015 & & & - & b 61 \\
\hline - . . - & - n. & - & 4. 022 & $89.87^{\circ}$ & - & e 62 \\
\hline - . . . & - - & - & 4.026 & $89.88^{\circ}$ & $\ldots \ldots$ & е 63 \\
\hline - . . . & - - & -..... & 4. 030 & $89.82^{\circ}$ & .... & e 64 \\
\hline 3. 918 & 4. 115 & 1. 050 & & & & 65 \\
\hline 3. 969 & 4. 103 & 1. 034 & ..... & . & - & 66 \\
\hline 3. 990 & 4. 098 & 1. 027 & - & - & - & 67 \\
\hline 4. 011 & 4. 096 & 1. 021 & -..... & ....... & - & 68 \\
\hline 4. 017 & 4. 098 & 1. 020 & & & - & 69 \\
\hline & -....- & -..... & 4.048 & $89.87^{\circ}$ & $\ldots$ & ๑ 70 \\
\hline ..... & ...... & ....... & 4. 048 & $89.80^{\circ}$ & -...... & 71 \\
\hline$\ldots$ & - & ....... & 4. 055 & $89.73^{\circ}$ & ....... & 72 \\
\hline$\ldots$ & ...... & ....... & 4. 058 & $89.77^{\circ}$ & -...... & 73 \\
\hline ..... & ....... & ....... & 4. 055 & $89.77^{\circ}$ & ....... & 74 \\
\hline$\ldots$ & ...... & -..... & 4. 070 & $89.78^{\circ}$ & ........ & 75 \\
\hline - & - & - n..... & 4. 109 & $89.80^{\circ}$ & $\ldots$ & 76 \\
\hline
\end{tabular}

a See Table 1 for composition of specimens.

b Predominantly tetragonal with minor content of rhombohedral phase. - Also contained non-ferroelectric phases.

Although listed here for convenience as tetragonal, $\mathrm{c} / \mathrm{a}<1$, the superstructure lines observed for these solid solutions have been interpreted for pure $\mathrm{PbZrO}_{3}$ by Sawaguchi, Maniwa, and Hoshino [18] as indication of a larger unit cell with

orthorhombic symmetry. Probably the limiting rhombohedral composition. 
TABLE 3. Dielectric properties at room temperature, Curie temperature and peak dielectric constant of solid-solution compositions.

\begin{tabular}{|c|c|c|c|c|c|c|c|c|c|c|}
\hline \multirow{3}{*}{$\begin{array}{l}\text { Num- } \\
\text { ber a }\end{array}$} & \multicolumn{8}{|c|}{$\begin{array}{l}\text { Dielectic constant }(\epsilon) \text { and dissipation factor (DF) } \\
\text { at } 25^{\circ} \mathrm{C}\end{array}$} & \multicolumn{2}{|c|}{$\begin{array}{c}\text { Curie point at } \\
1 \mathrm{Mc}\end{array}$} \\
\hline & \multicolumn{2}{|c|}{$1 \mathrm{kc}$} & \multicolumn{2}{|c|}{$50 \mathrm{kc}$} & & $\mathrm{Me}$ & & $\mathrm{Mc}$ & & \\
\hline & $\epsilon$ & DF & $\epsilon$ & DF & $\epsilon$ & DF & $\epsilon$ & DF & ture & \\
\hline & & $\%$ & & $\%$ & & $\%$ & & $\%$ & ${ }^{\circ} \mathrm{C}$ & \\
\hline 1 & 221 & 5.5 & 204 & 1.1 & 203 & 0.64 & 202 & 0.48 & 420 & 7900 \\
\hline 2 & 338 & 1. 4 & 328 & 0.83 & 325 & .67 & 321 & .87 & 405 & 7800 \\
\hline 3 & 641 & 1. 4 & 619 & .91 & 610 & .83 & 605 & 1.3 & 400 & 6900 \\
\hline 4 & 782 & 0.36 & 772 & .48 & 766 & .69 & 751 & 1.6 & 370 & 7400 \\
\hline 5 & 606 & .64 & 599 & .91 & 585 & 1. 2 & 567 & 2.6 & 330 & 8400 \\
\hline 6 & 533 & .74 & 510 & .96 & 500 & 1.4 & 489 & 2.6 & 350 & 7900 \\
\hline 7 & 524 & 1. 6 & 510 & 1.6 & 499 & 1.4 & 486 & 2. 2 & 350 & 4400 \\
\hline 8 & 388 & 2.3 & 373 & 2.3 & 360 & 2.8 & 339 & 4.3 & 320 & 5400 \\
\hline $\begin{array}{r}9 \\
10\end{array}$ & $\begin{array}{l}375 \\
322\end{array}$ & $\begin{array}{l}1.6 \\
1.6\end{array}$ & $\begin{array}{l}369 \\
322\end{array}$ & $\begin{array}{l}2.0 \\
2.0\end{array}$ & $\begin{array}{l}355 \\
309\end{array}$ & $\begin{array}{l}2.8 \\
2.7\end{array}$ & $\begin{array}{l}329 \\
269\end{array}$ & $\begin{array}{l}6.2 \\
4.8\end{array}$ & $\begin{array}{l}280 \\
235\end{array}$ & $\begin{array}{l}4400 \\
3600\end{array}$ \\
\hline 11 & 240 & 118 & 235 & 059 & 233 & 7 & 231 & 10 & 35 & 6100 \\
\hline 12 & 631 & $\begin{array}{l}1.8 \\
0.62\end{array}$ & 618 & $\begin{array}{r}0.59 \\
.59\end{array}$ & $\begin{array}{l}612 \\
612\end{array}$ & $\begin{array}{l}0.83 \\
.83\end{array}$ & 603 & $\begin{array}{l}1.0 \\
1.5\end{array}$ & $\begin{array}{l}503 \\
270\end{array}$ & 6800 \\
\hline 13 & 941 & .71 & 922 & .83 & 910 & 1. 1 & 887 & 2.2 & 255 & 5900 \\
\hline 14 & 1110 & .63 & 1100 & .83 & 1070 & 1. 0 & 960 & 1.9 & 235 & 5700 \\
\hline 15 & 1260 & 1. 0 & 1230 & 1.1 & 1200 & 1.5 & 1050 & 3. 0 & 235 & 5800 \\
\hline 16 & 776 & 1.2 & 741 & 1.5 & 723 & 2.3 & 671 & 4. 2 & 225 & 4600 \\
\hline 17 & 475 & 1.4 & 463 & 1.4 & 451 & 2.0 & 444 & 3.6 & 210 & 2800 \\
\hline 18 & 214 & 1.6 & 205 & 1.4 & 200 & 2.3 & 175 & 3.1 & 205 & b 892 \\
\hline c 19 & 114 & 0.48 & 112 & 0.25 & 112 & 0.28 & 111 & 0.48 & 220 & d 1430 \\
\hline 20 & $\begin{array}{l}114 \\
122\end{array}$ & $\begin{array}{l}0.78 \\
.38\end{array}$ & $\begin{array}{l}119 \\
\text {. }\end{array}$ & $\begin{array}{l}0.25 \\
.25\end{array}$ & 119 & $\begin{array}{l}0.20 \\
.37\end{array}$ & $\begin{array}{l}119 \\
119\end{array}$ & $\begin{array}{r}.70 \\
.56\end{array}$ & 230 & $\begin{array}{l}1400 \\
\text { d } 1010\end{array}$ \\
\hline c 21 & 137 & .45 & 136 & .33 & 135 & .38 & 135 & .38 & 225 & $\mathrm{~d} 694$ \\
\hline 22 & 134 & .45 & 132 & .25 & 132 & .24 & $\begin{array}{l}132 \\
132\end{array}$ & .44 & 265 & d 383 \\
\hline c 23 & 145 & .91 & 141 & .20 & 141 & .17 & 141 & $\begin{array}{l}.44 \\
.26\end{array}$ & $\begin{array}{l}200 \\
310\end{array}$ & $\begin{array}{l}385 \\
d 238\end{array}$ \\
\hline 24 & 220 & 4. 0 & 217 & 0.25 & 216 & 0.29 & 215 & 0.50 & (400) & (e) \\
\hline 25 & 535 & 0.24 & 533 & .25 & 532 & $\begin{array}{l}0.29 \\
.38\end{array}$ & 531 & $\begin{array}{l}0.50 \\
.56\end{array}$ & 360 & 13000 \\
\hline 26 & ${ }^{f} 660$ & .24 & 664 & .25 & 660 & .50 & 654 & .63 & 330 & 8700 \\
\hline 27 & 815 & .34 & 802 & 3 & 801 & .50 & 795 & 1. 2 & 330 & 8100 \\
\hline 28 & 827 & .45 & 818 & .50 & 817 & 1.0 & 801 & 1.4 & 320 & 8200 \\
\hline 29 & 641 & .50 & 632 & 1.0 & 632 & 1. 0 & 613 & 2.0 & 330 & 8600 \\
\hline $\begin{array}{l}30 \\
31\end{array}$ & $\begin{array}{l}502 \\
356\end{array}$ & .67 & $\begin{array}{l}501 \\
354\end{array}$ & $\begin{array}{l}1.1 \\
1.2\end{array}$ & $\begin{array}{l}491 \\
354\end{array}$ & $\begin{array}{l}1.7 \\
1.9\end{array}$ & $\begin{array}{l}472 \\
329\end{array}$ & 3. 1 & $\begin{array}{l}300 \\
225\end{array}$ & $\begin{array}{r}14000 \\
4100\end{array}$ \\
\hline 32 & & 0.49 & กา? & 0 & 332 & 0.42 & ק00 & 0.7 & 250 & 0 \\
\hline $\begin{array}{l}32 \\
33\end{array}$ & $\begin{array}{l}3.34 \\
507\end{array}$ & $\begin{array}{l}0.42 \\
.26\end{array}$ & $\begin{array}{l}335 \\
504\end{array}$ & $\begin{array}{l}0.28 \\
.28\end{array}$ & $\begin{array}{l}352 \\
499\end{array}$ & $\begin{array}{r}0.42 \\
.40\end{array}$ & $\begin{array}{l}329 \\
495\end{array}$ & .91 & $\begin{array}{l}550 \\
330\end{array}$ & $\begin{array}{l}8000 \\
7100\end{array}$ \\
\hline 34 & 976 & 45 & 962 & .50 & 956 & .77 & 941 & 1. 5 & 300 & 8100 \\
\hline 35 & 836 & 66 & 814 & .66 & 808 & 1.1 & 776 & 2. 2 & 270 & 8800 \\
\hline $\begin{array}{l}00 \\
36\end{array}$ & 717 & .77 & 701 & .91 & 686 & 1.4 & 661 & 2.6 & 270 & 8600 \\
\hline $\begin{array}{l}30 \\
37\end{array}$ & 645 & .83 & 629 & 1. 0 & 616 & $\begin{array}{l}1.4 \\
1.5\end{array}$ & 595 & 2.9 & 240 & 8000 \\
\hline 38 & 554 & 1.1 & 545 & 1. 6 & 534 & 2. 2 & 506 & 4.2 & 250 & 8300 \\
\hline 39 & 406 & 0.91 & 399 & 1.1 & 391 & 1. 9 & 375 & 4. 2 & 200 & 6500 \\
\hline 40 & 465 & 0.34 & 461 & 0.32 & 460 & 0.43 & 453 & 1.0 & 300 & 7100 \\
\hline $\begin{array}{l}40 \\
41\end{array}$ & $\begin{array}{r}405 \\
1110\end{array}$ & $\begin{array}{l}0.34 \\
.53\end{array}$ & $\begin{array}{r}461 \\
1073\end{array}$ & $\begin{array}{r}0.52 \\
.56\end{array}$ & $\begin{array}{r}400 \\
1063\end{array}$ & $\begin{array}{r}0.43 \\
.72\end{array}$ & $\begin{array}{r}453 \\
1049\end{array}$ & $\begin{array}{l}1.0 \\
1.5\end{array}$ & $\begin{array}{l}300 \\
250\end{array}$ & 7800 \\
\hline $\begin{array}{l}41 \\
42\end{array}$ & $\begin{array}{r}110 \\
941\end{array}$ & .91 & $\begin{array}{r}10.3 \\
921\end{array}$ & $\begin{array}{l}.50 \\
.91\end{array}$ & $\begin{array}{r}1003 \\
904\end{array}$ & 1.3 & $\begin{array}{r}1049 \\
874\end{array}$ & $\begin{array}{l}1.5 \\
2.2\end{array}$ & $\begin{array}{l}260 \\
260\end{array}$ & 8300 \\
\hline $\begin{array}{l}42 \\
43\end{array}$ & $\begin{array}{l}941 \\
860\end{array}$ & 91 & $\begin{array}{l}921 \\
832\end{array}$ & $\begin{array}{l}.91 \\
1.2\end{array}$ & $\begin{array}{l}904 \\
815\end{array}$ & $\begin{array}{l}1.3 \\
1.5\end{array}$ & $\begin{array}{l}8>4 \\
793\end{array}$ & $\begin{array}{l}2.2 \\
2.9\end{array}$ & $\begin{array}{l}260 \\
260\end{array}$ & $\begin{array}{r}8300 \\
11000\end{array}$ \\
\hline 44 & 792 & 83 & 782 & 1. 2 & 762 & 1. 7 & 746 & 1. 2 & 250 & 8500 \\
\hline 45 & 611 & 1.2 & 594 & 1.4 & 581 & 2.3 & 550 & 1.8 & 200 & $\begin{array}{l}6000 \\
6600\end{array}$ \\
\hline $\begin{array}{l}70 \\
46\end{array}$ & 552 & 1. 6 & 549 & 2.1 & $\begin{array}{l}581 \\
526\end{array}$ & $\begin{array}{l}2.3 \\
2.9\end{array}$ & $\begin{array}{l}500 \\
502\end{array}$ & $\begin{array}{l}1.8 \\
5.5\end{array}$ & 170 & $\begin{array}{l}6500 \\
6500\end{array}$ \\
\hline $\begin{array}{l}40 \\
47\end{array}$ & $\begin{array}{l}527 \\
427\end{array}$ & $\begin{array}{l}1.0 \\
1.0\end{array}$ & $\begin{array}{l}349 \\
423\end{array}$ & $\begin{array}{l}2.1 \\
1.3\end{array}$ & $\begin{array}{l}520 \\
411\end{array}$ & $\begin{array}{l}2.9 \\
2.0\end{array}$ & $\begin{array}{l}502 \\
391\end{array}$ & $\begin{array}{l}5.5 \\
1.4\end{array}$ & $\begin{array}{l}170 \\
140\end{array}$ & $\begin{array}{l}0500 \\
4600\end{array}$ \\
\hline $\begin{array}{l}07 \\
\circ 48\end{array}$ & 443 & $\begin{array}{l}1.0 \\
1.2\end{array}$ & 441 & $\begin{array}{l}1.0 \\
1.6\end{array}$ & $\begin{array}{l}411 \\
429\end{array}$ & 2.4 & $\begin{array}{l}506 \\
401\end{array}$ & $\begin{array}{l}1.4 \\
4.5\end{array}$ & $\begin{array}{l}140 \\
160\end{array}$ & $\begin{array}{l}4000 \\
\mathrm{~g} 2880\end{array}$ \\
\hline $\begin{array}{r}40 \\
\end{array} 99$ & 365 & 0.42 & 365 & 0.59 & 362 & 0.77 & $\begin{array}{l}400 \\
355\end{array}$ & $\begin{array}{l}4.0 \\
1.7\end{array}$ & 180 & d 1640 \\
\hline ' 50 & 203 & .43 & 197 & .59 & 194 & .83 & 190 & 1.8 & 200 & d 1080 \\
\hline${ }^{\circ} 51$ & 442 & 0.50 & 442 & 0.62 & 435 & 0.83 & 429 & 1.4 & 310 & 4000 \\
\hline 52 & 845 & .56 & 844 & .87 & 831 & 1. & 814 & & & 4700 \\
\hline 53 & 962 & .63 & 963 & .83 & 948 & 1. 0 & 932 & 1.7 & 250 & 4700 \\
\hline c 54 & 910 & .87 & 917 & 1.1 & 898 & 1. 4 & 869 & 2.1 & 270 & 4300 \\
\hline 55 & 832 & 91 & 827 & 1. 4 & 804 & 1. 9 & 773 & 3.6 & 260 & 4700 \\
\hline 56 & 780 & 1.1 & 795 & 1. 6 & 768 & 2. 1 & 733 & 4. 2 & 260 & 4600 \\
\hline 57 & 564 & 0.91 & 580 & 1.4 & 562 & 2. 0 & 536 & 4.0 & 180 & 5400 \\
\hline 58 & 452 & 1. 0 & 460 & 1. 4 & 446 & 2. 0 & 428 & 4.0 & 150 & g 1740 \\
\hline c 59 & 497 & 0.50 & 495 & 0.50 & 490 & 0.59 & 485 & 11 & (h) & \\
\hline $\begin{array}{r}59 \\
\mathrm{c} 60\end{array}$ & $\begin{array}{l}498 \\
648\end{array}$ & & $\begin{array}{l}495 \\
645\end{array}$ & & $\begin{array}{l}490 \\
637\end{array}$ & $\begin{array}{r}0.59 \\
.63\end{array}$ & $\begin{array}{l}485 \\
630\end{array}$ & & (b) & \\
\hline $\begin{array}{l}\text { c } 61 \\
\text {. }\end{array}$ & $\begin{array}{l}648 \\
693\end{array}$ & .63 & $\begin{array}{l}645 \\
690\end{array}$ & $\begin{array}{l}53 \\
.59\end{array}$ & $\begin{array}{l}031 \\
682\end{array}$ & .71 & $\begin{array}{l}030 \\
680\end{array}$ & $\begin{array}{l}1.5 \\
1.1\end{array}$ & (h) & \\
\hline с 6 & 628 & .71 & 637 & .71 & 625 & .91 & 611 & 1. 8 & (b) & \\
\hline с 63 & 580 & .48 & 603 & .83 & 591 & 1. 2 & $\begin{array}{l}578 \\
578\end{array}$ & $\begin{array}{l}1.8 \\
2.3\end{array}$ & (h) & \\
\hline $\begin{array}{l}-64 \\
\cdot 64\end{array}$ & 556 & .53 & 580 & .91 & 569 & 1.3 & 555 & 2.7 & (h) & $\cdots$ \\
\hline 65 & & 16 & 215 & 0 & 515 & 030 & 114 & 05 & (h) & \\
\hline $\begin{array}{l}{ }^{\circ} 66 \\
67\end{array}$ & $\begin{array}{l}218 \\
439\end{array}$ & $\begin{array}{l}1.6 \\
0.21\end{array}$ & $\begin{array}{l}215 \\
436\end{array}$ & $\begin{array}{l}0.29 \\
21\end{array}$ & $\begin{array}{l}215 \\
436\end{array}$ & $\begin{array}{l}0.30 \\
30\end{array}$ & $\begin{array}{l}214 \\
435\end{array}$ & 0.53 & $\begin{array}{l}\text { (n) } \\
350\end{array}$ & 300 \\
\hline 68 & $\begin{array}{l}459 \\
690\end{array}$ & $\begin{array}{l}0.21 \\
.17\end{array}$ & $\begin{array}{l}450 \\
688\end{array}$ & .22 & $\begin{array}{l}450 \\
687\end{array}$ & .31 & $\begin{array}{l}450 \\
684\end{array}$ & .0 & 340 & 8100 \\
\hline 69 & 764 & .20 & 766 & 20 & 761 & .40 & 759 & .71 & $\begin{array}{l}54 \\
35\end{array}$ & 7400 \\
\hline 70 & 672 & .24 & 678 & .37 & 676 & .59 & 670 & 1.0 & 330 & 7100 \\
\hline 71 & 590 & 25 & 595 & .45 & 593 & .71 & 583 & 1.7 & 315 & 7800 \\
\hline 72 & 522 & 27 & 526 & .48 & 523 & .76 & 514 & 2.3 & 325 & 7300 \\
\hline 73 & 478 & 29 & 482 & 53 & 479 & 83 & 470 & 1.8 & 310 & 7200 \\
\hline 74 & 466 & .91 & 464 & .83 & 458 & 1. 2 & $\begin{array}{l}710 \\
446\end{array}$ & $\begin{array}{l}1.8 \\
2.5\end{array}$ & 275 & 5300 \\
\hline 75 & 472 & 1.6 & 471 & 1.2 & 462 & 1.5 & 446 & 3.5 & 250 & 5400 \\
\hline $\begin{array}{l}10 \\
\circ 66\end{array}$ & 469 & $\begin{array}{l}1.0 \\
2.0\end{array}$ & $\begin{array}{l}711 \\
469\end{array}$ & 1. 9 & $\begin{array}{l}702 \\
454\end{array}$ & $\begin{array}{l}1.5 \\
2.5\end{array}$ & 430 & $\begin{array}{l}0.0 \\
6.2\end{array}$ & 200 & 4200 \\
\hline
\end{tabular}

TABLE 4. Radial electromechanical coupling coefficient $\left(K_{\mathbf{r}}\right)$ observed for specimens one week after room-temperature polarization under conditions indicated.

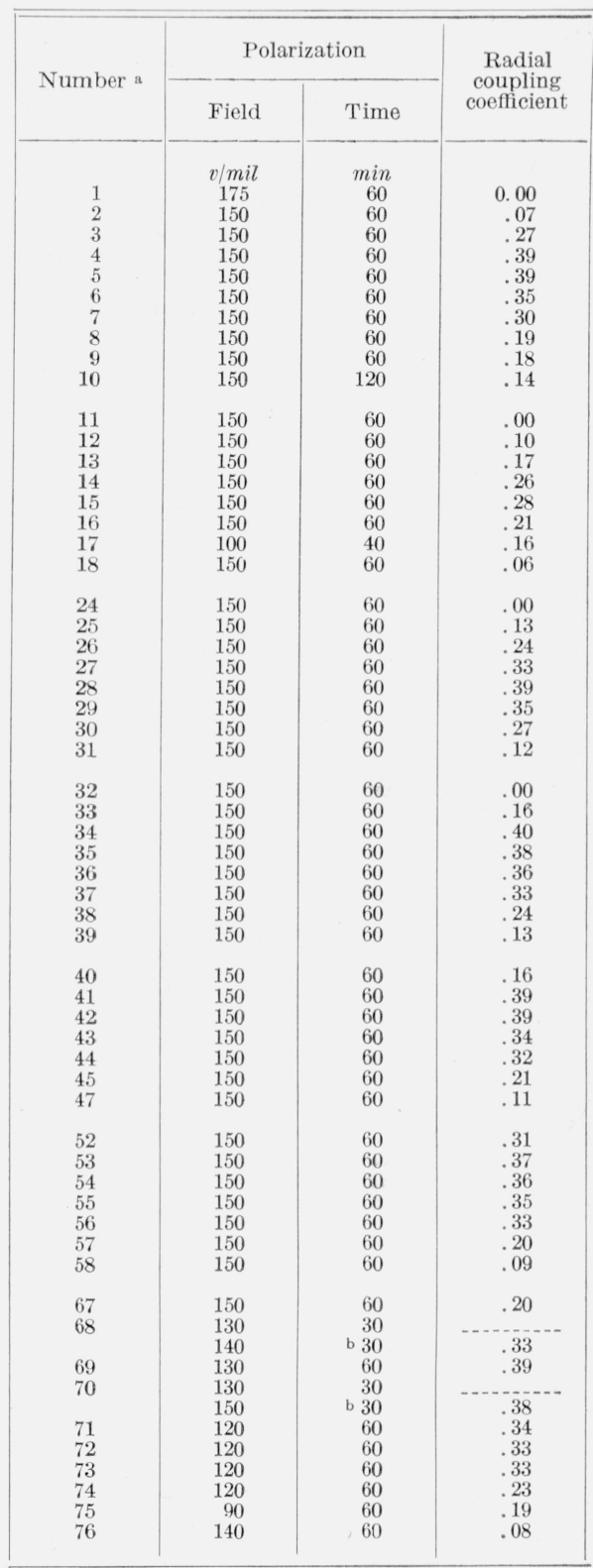

a See table 1 for composition of specimens.

b The polarizing treatments indicated were successive. a See table 1 for composition of specimens.

b Peak dielectric constant low because of dilution of the ferroelectric phase by a non-ferroelectric phase.

Not matured (see table 1 )

a This

e Excessive dielectric loss prevented determination of dielectric constant at Curie point.

${ }^{f}$ In several instances, of which this is typical, the dielectric constant at $1 \mathrm{kc}$ appears too low because of time, temperature, and measuring voltage differences. $\mathrm{g}$ This composition is ferroelectric at room temperature, but becomes antiferroelectric before the Curie temperature is reached. 
the dielectric constant and the radial coupling coefficient at room temperature exhibited a pronounced maximum as the composition approached the phase boundary, as shown in figure 4 . The compositions 52.5 and 55.0 mole percent $\mathrm{PbZrO}_{3}$, close to the boundary, approached 0.4 radial coupling coefficient value. Room temperature polarization of the solid solutions rich in $\mathrm{Pb}^{\prime} \mathrm{TiO}_{3}$ had little, if any, effect.

The coupling coefficient, frequency constant, $d_{31}$, and $g_{31}$ are plotted in figures 5 and 6 as a function of temperature for the two compositions near the phase boundary. The values plotted in these figures are given in table 5. The radial coupling coefficients at room temperature for the limiting rhombohedral and the limiting tetragonal compositions were high. That of the limiting rhombohedral composition, 55 mole percent $\mathrm{PbZrO}_{3}$, remained relatively high at elevated temperatures. It was still over 0.3 at $275^{\circ} \mathrm{C}$, although limited experiments indicated that the original properties were not fully regained upon cooling from the high temperature. The value for the room temperature radial coupling coefficient shown for this specimen in tables 4 and 5 are slightly different. The slightly lower value shown in table 5 is due to an aging effect on the specimen. Additional refinement of composition to approach the boundary more closely might yield still better properties, but was not attempted here.

The dielectric constant and the resonance frequency are both sensitive indications of polymorphic inversion. They indicate, for these compositions, no inversions below the Curie temperature (unless they occur below $-50^{\circ} \mathrm{C}$, the lower limit of our dielectric tests).

\section{b. $\mathrm{PbTiO}_{3}-\mathrm{PbO}: \mathrm{SnO}_{2}$}

Many similarities were observed between the effect of $\mathrm{PbO}: \mathrm{SnO}_{2}$ and that of $\mathrm{PbZrO}_{3}$ when added in solid solution to $\mathrm{PbTiO}_{3}$. For the $\mathrm{Pb}(\mathrm{Sn}, \mathrm{Ti}) \mathrm{O}_{3}$ series, also, the presence of a morphotropic transformation somewhere between 55 and 60 mole percent $\mathrm{PbO}$ : $\mathrm{SnO}_{2}$ was indicated. As $\mathrm{Sn}^{4+}$ replaced $\mathrm{Ti}^{4+}$ in $\mathrm{PbTiO}_{3}$, the tetragonal c/a ratio diminished from 1.06, becoming 1.01 for the composition containing 55 mole percent $\mathrm{PbO}: \mathrm{SnO}_{2}$. For the composition containing 60 mole percent $\mathrm{PbO}: \mathrm{SnO}_{2}$, however, a pseudocubic perovskite structure was indicated by the diffraction pattern. The $\alpha_{2}$ peaks usually observed for a cubic structure were not visible. Observation of ferroelectric hysteresis loops by the usual method [25], and of the other dielectric and piezoelectric properties, made it clear that the true symmetry was really pseudocubic rather than cubic. Figure 7 shows how the substitution of $\mathrm{PbO}: \mathrm{SnO}_{2}$ in $\mathrm{PbTiO}_{3}$ reduces the Curie temperature. It is also, in a rudimentary way, an indication of the solid-state phase diagram.

As further evidence of the existence of the morphotropic transformation, it may be seen in figure 8 that the room-temperature dielectric constant rose to a sharp maximum as the composition approached that of the phase boundary. Here, too, maximum values of coupling coefficient were observed. They were less than 0.3 . In this respect they are not outstand- ing. Figures 9 and 10 show the variation of piezoelectric properties with temperature for two compositions near the phase boundary. The values plotted in these figures are given in table 5.

As still more $\mathrm{PbO}: \mathrm{SnO}_{2}$ was added, the solid solution became incomplete. Ceramics rich in $\mathrm{PbO}: \mathrm{SnO}_{2}$ consisted of a ferroelectric perovskite phase and one or more nonferroelectric phases which served as diluents. Although the composition with 75 mole percent $\mathrm{PbO}: \mathrm{SnO}_{2}$ still had a ferroelectrictype hysteresis loop, the value of the peak dielectric constant at its Curie point was much lower than usually observed for a good-quality ceramic consisting of a single ferroelectric phase. The diluent phases consisted of fluorite-type $\mathrm{PbO}: \mathrm{SnO}_{2}$ and, in some instances, free $\mathrm{SnO}_{2}$. Evidently this composition exceeds the limit of solid solubility of $\mathrm{PbO}: \mathrm{SnO}_{2}$ in $\mathrm{PbTiO}_{3}$.

Nomura and Sawada [26] reported on solid solutions of $\mathrm{PbO}: \mathrm{SnO}_{2}$ and $\mathrm{PbTiO}_{3}$. Although difficulties were encountered in translation from the Japanese, it would appear that our results and theirs differed in certain respects. They reported limited solid solubility when $\mathrm{PbO}: \mathrm{SnO}_{2}$ exceeds 75 mole percent; our results concur. However, they did not observe any morphotropic transition near 55 mole percent $\mathrm{PbO}: \mathrm{SnO}_{2}$. The dielectric constant values they reported for solid solutions containing less than 75 mole percent $\mathrm{PbO}: \mathrm{SnO}_{2}$ are so low that one might assume that appreciable loss of $\mathrm{PbO}$ by volatilization occurred. As an example, their equimolar composition had, at room temperature, a dielectric constant of about 100. Our measured values for ceramics of like composition were nearly 900, and the composition was found to be near the phase boundary. At the Curie point, the differences are even more striking Our peak dielectric constant for the composition with 50 mole percent $\mathrm{PbO}: \mathrm{SnO}_{2}$ was almost 6,000. The peak dielectric constant observed for this composition by Nomura and Sawada was only about 800 at the Curie temperature.

\section{c. $\mathrm{PbZrO}_{3}-\mathrm{PbO}: \mathrm{SnO}_{2}$}

X-ray diffraction powder patterns of $\mathrm{PbZrO}_{3}-$ $\mathrm{PbO}: \mathrm{SnO}_{2}$ solid solutions revealed that $\mathrm{PbO}: \mathrm{SnO}_{2}$ is soluble in $\mathrm{PbZrO}_{3}$ up to the maximum proportions tried, 70 mole percent $\mathrm{PbO}: \mathrm{SnO}_{2}$. At the temperatures necessary to produce low-absorption ceramics, there was no observable tendency toward dissociation to either $\mathrm{Pb}_{2} \mathrm{SnO}_{4}+$ free $\mathrm{SnO}_{2}$ or to a fluorite-type lead stannate.

The structures of the solid solutions were singlephase perovskites. They appeared to be isostructural with $\mathrm{PbZrO}_{3}$ and showed similar superstructure lines. As $\mathrm{Sn}^{4+}$ replaces $\mathrm{Zr}^{4+}$ in the lattice, the primitive pseudotetragonal cell size decreases, and its c/a ratio, which remains less than one throughout, approaches closer to unity. Simultaneously, the Curie temperature increases, although the magnitude of the peak dielectric constant diminishes greatly. Kittel [19] has pointed out that a high peak dielectric constant at the Curie temperature is not a necessary condition for antiferroelectricity. It is felt that this series illustrates his point. 
TABLE 5. Electromechanical properties at elevated temperatures of selected specimens of compositions close to morphotropic solidsolution phase boundaries. The properties listed are the radial coupling coefficient $\left(k_{\mathrm{r}}\right)$, the frequency constant $(f$. $c$., radial resonance frequency multiplied by disk radius), and the $d_{31}$ and $g_{31}$ piezoelectric constants

\begin{tabular}{|c|c|c|c|c|c|c|c|c|c|c|c|c|c|c|c|c|c|}
\hline \multirow{2}{*}{ No. } & \multirow{2}{*}{$\begin{array}{r}\text { Structure and } \\
\text { sition }\end{array}$} & \multirow{2}{*}{ compo- } & \multirow{2}{*}{$\begin{array}{l}\text { Prop- } \\
\text { erty a }\end{array}$} & \multicolumn{14}{|c|}{ Temperature, ${ }^{\circ} \mathrm{C}$} \\
\hline & & & & $25^{\circ}$ & $50^{\circ}$ & $75^{\circ}$ & $100^{\circ}$ & $125^{\circ}$ & $150^{\circ}$ & $175^{\circ}$ & $200^{\circ}$ & $225^{\circ}$ & $250^{\circ}$ & $275^{\circ}$ & $300^{\circ}$ & $325^{\circ}$ & $350^{\circ}$ \\
\hline 4 & $\begin{array}{l}\text { tetragonal } \\
\mathrm{PbTiO}_{3} \\
\mathrm{PbZrO}_{3}\end{array}$ & $\begin{array}{l}47.5 \\
52.5\end{array}$ & $\begin{aligned} k_{\mathrm{r}} \\
\text { f. c. } \\
\mathrm{d}_{31} \\
\mathrm{~g}_{31}\end{aligned}$ & $\begin{array}{r}0.38 \\
1132 \\
67 \\
9.8\end{array}$ & $\begin{array}{l}0.40 \\
1132 \\
74 \\
9.6\end{array}$ & $\begin{array}{l}0.38 \\
1135 \\
73 \\
9.0\end{array}$ & $\begin{array}{r}0.40 \\
138 \\
78 \\
9.1\end{array}$ & $\begin{array}{l}0.37 \\
1145 \\
76 \\
8.0\end{array}$ & $\begin{array}{l}0.35 \\
1152 \\
75 \\
7.3\end{array}$ & $\begin{array}{l}0.32 \\
1161 \\
73 \\
6.0\end{array}$ & $\begin{array}{r}\text { b } 0.24 \\
1169 \\
63 \\
4.0\end{array}$ & $\begin{array}{l}0.28 \\
1169 \\
\text { (c) } \\
\text { (c) }\end{array}$ & $\begin{array}{l}0.26 \\
1184 \\
-\cdots \\
-\cdots-\end{array}$ & $\begin{array}{l}0.16 \\
1188 \\
-\cdots\end{array}$ & $\begin{array}{l}-\cdots \\
\cdots-. . \\
-\cdots\end{array}$ & $\begin{array}{l}\cdots-. \\
\cdots-. \\
-\cdots\end{array}$ & $\begin{array}{l}\cdots \\
\cdots \\
\cdots \\
\cdots-.\end{array}$ \\
\hline 5 & $\begin{array}{l}\text { rhombohedral } \\
\mathrm{PbTiO}_{3} \\
\mathrm{PbZrO}_{3}\end{array}$ & $\begin{array}{l}45 \\
55\end{array}$ & $\begin{array}{r}k_{\mathrm{r}} \\
\text { f. c. } \\
\mathrm{d}_{31} \\
\mathrm{~g}_{31}\end{array}$ & $\begin{array}{r}\mathrm{d} 0.36 \\
1080 \\
56 \\
11.7\end{array}$ & $\begin{array}{r}0.37 \\
1074 \\
64 \\
12.2\end{array}$ & $\begin{array}{r}0.37 \\
1063 \\
70 \\
11.9\end{array}$ & $\begin{array}{r}0.38 \\
1055 \\
74 \\
11.8\end{array}$ & $\begin{array}{r}0.37 \\
1050 \\
77 \\
11.2\end{array}$ & $\begin{array}{r}0.37 \\
1043 \\
81 \\
10.6\end{array}$ & $\begin{array}{l}0.36 \\
1042 \\
87 \\
9.6\end{array}$ & $\begin{array}{l}0.36 \\
1039 \\
94 \\
8.6\end{array}$ & $\begin{array}{l}0.34 \\
1038 \\
98 \\
7.6\end{array}$ & $\begin{array}{l}0.33 \\
1038 \\
110 \\
6.3\end{array}$ & $\begin{array}{l}0.30 \\
1041 \\
117 \\
5.0\end{array}$ & $\begin{array}{l}0.27 \\
1046 \\
127 \\
3.5\end{array}$ & $\begin{array}{l}021 \\
1051 \\
131 \\
2.1\end{array}$ & $\begin{array}{l}0.13 \\
1087 \\
(\mathrm{c}) \\
(\mathrm{c})\end{array}$ \\
\hline 15 & $\begin{array}{l}\text { tetragonal } \\
\mathrm{PbTiO}_{3} \\
\mathrm{PbO}: \mathrm{SnO}_{2}\end{array}$ & $\begin{array}{l}45 \\
55\end{array}$ & $\begin{array}{l}k_{\mathrm{r}} \\
\text { f.c. } \\
\mathrm{d}_{31} \\
\mathrm{~g}_{31}\end{array}$ & $\begin{array}{l}0.25 \\
1152 \\
46 \\
5.1\end{array}$ & $\begin{array}{l}0.26 \\
1138 \\
54 \\
4.5\end{array}$ & $\begin{array}{r}0.26 \\
1141 \\
57 \\
4.1\end{array}$ & $\begin{array}{l}0.24 \\
1149 \\
55 \\
3.5\end{array}$ & $\begin{array}{l}0.22 \\
1159 \\
57 \\
3.0\end{array}$ & $\begin{array}{l}0.20 \\
1166 \\
56 \\
2.4\end{array}$ & $\begin{array}{l}0.17 \\
1183 \\
58 \\
1.6\end{array}$ & $\begin{array}{l}0.07 \\
1263 \\
27 \\
0.5\end{array}$ & $\begin{array}{l}\cdots \\
\cdots-. \\
\cdots-. \\
\cdots\end{array}$ & $\begin{array}{l}\cdots \\
\cdots-. \\
\cdots \cdots \\
\cdots-.\end{array}$ & $\begin{array}{l}\cdots- \\
\cdots- \\
\cdots-.\end{array}$ & $\begin{array}{l}\cdots \\
\cdots \cdots \\
\cdots \cdots\end{array}$ & $\begin{array}{l}\cdots \\
\cdots \cdots \\
\cdots \cdots\end{array}$ & $\begin{array}{l}--\cdot \\
-\cdots \\
-\cdots\end{array}$ \\
\hline 16 & $\begin{array}{l}\text { pseudo- } \\
\text { cubic } \\
\mathrm{PbTiO}_{3} \\
\mathrm{PbO}: \mathrm{SnO}_{2}\end{array}$ & $\begin{array}{l}40 \\
60\end{array}$ & $\begin{array}{l}k_{\mathrm{r}} \\
\text { f.c. } \\
\mathrm{d}_{31} \\
\mathrm{~g}_{31}\end{array}$ & $\begin{array}{l}0.20 \\
1171 \\
28 \\
5.0\end{array}$ & $\begin{array}{r}0.21 \\
1154 \\
36 \\
4.5\end{array}$ & $\begin{array}{l}0.21 \\
1146 \\
40 \\
4.2\end{array}$ & $\begin{array}{l}0.21 \\
1140 \\
45 \\
3.6\end{array}$ & $\begin{array}{l}0.18 \\
1145 \\
48 \\
2.6\end{array}$ & $\begin{array}{l}0.17 \\
1156 \\
48 \\
2.2\end{array}$ & $\begin{array}{l}0.12 \\
1195 \\
44 \\
1.2\end{array}$ & $\begin{array}{l}\cdots \\
\cdots \\
\cdots \cdots \\
\cdots-.\end{array}$ & $\begin{array}{l}\ldots . . \\
\cdots \\
\cdots \cdots \\
-\cdots\end{array}$ & $\begin{array}{l}-\cdot- \\
\cdots \cdots \\
\cdots \cdots\end{array}$ & $\begin{array}{l}\cdots \\
\cdots \cdots \\
\cdots \cdots\end{array}$ & $\begin{array}{l}\cdots \\
\cdots \cdots \\
\cdots \cdots \\
\cdots \cdots\end{array}$ & $\begin{array}{l}-\cdots \\
\cdots \\
\cdots \cdots\end{array}$ & $\begin{array}{l}-\cdots \\
\cdots \cdots \\
\cdots \cdots\end{array}$ \\
\hline 27 & $\begin{array}{l}\text { tetragonal } \\
\mathrm{PbTiO}_{3} \\
\mathrm{PbZrO}_{3} \\
\mathrm{PbO}: \mathrm{SnO}_{2}\end{array}$ & $\begin{array}{l}49.5 \\
40.5 \\
10.0\end{array}$ & $\begin{array}{l}k_{r} \\
\text { f.c. } \\
d_{31} \\
g_{31}\end{array}$ & $\begin{array}{r}0.33 \\
1142 \\
60 \\
7.8\end{array}$ & $\begin{array}{l}0.33 \\
1140 \\
\quad 64 \\
7.4\end{array}$ & $\begin{array}{l}0.32 \\
1142 \\
65 \\
7.1\end{array}$ & $\begin{array}{l}0.30 \\
1155 \\
69 \\
6.4\end{array}$ & $\begin{array}{l}0.29 \\
1163 \\
60 \\
6.1\end{array}$ & $\begin{array}{l}0.28 \\
1171 \\
58 \\
5.5\end{array}$ & $\begin{array}{l}0.27 \\
1179 \\
59 \\
5.1\end{array}$ & $\begin{array}{l}0.26 \\
1183 \\
62 \\
4.5\end{array}$ & $\begin{array}{l}0.25 \\
1186 \\
\cdots \\
\cdots\end{array}$ & $\begin{array}{l}0.23 \\
1185 \\
\cdots\end{array}$ & \begin{tabular}{l}
0.21 \\
1183 \\
\hdashline- \\
$\cdots$
\end{tabular} & \begin{tabular}{l}
0.14 \\
1186 \\
\hdashline
\end{tabular} & $\begin{array}{l}\cdots \\
\cdots \\
\cdots\end{array}$ & $\begin{array}{l}\cdots \\
\cdots \cdots \\
\cdots \cdots \\
\cdots-.\end{array}$ \\
\hline 28 & $\begin{array}{l}\text { rhombohedral } \\
\mathrm{PbTiO}_{3} \\
\mathrm{PbZrO} \\
\mathrm{PbO}: \mathrm{SnO}_{2}\end{array}$ & $\begin{array}{l}47.25 \\
42.75 \\
10.00\end{array}$ & $\begin{array}{l}k_{r} \\
\text { f.c. } \\
d_{31} \\
g_{31}\end{array}$ & $\begin{array}{r}0.39 \\
1145 \\
62 \\
9.7\end{array}$ & $\begin{array}{l}0.40 \\
1133 \\
68 \\
9.4\end{array}$ & $\begin{array}{l}0.39 \\
1130 \\
71 \\
8.9\end{array}$ & $\begin{array}{l}0.39 \\
1128 \\
76 \\
8.4\end{array}$ & $\begin{array}{r}0.39 \\
1131 \\
77 \\
7.9\end{array}$ & $\begin{array}{r}0.37 \\
1133 \\
80 \\
7.0\end{array}$ & $\begin{array}{l}0.35 \\
1139 \\
82 \\
6.2\end{array}$ & $\begin{array}{c}0.33 \\
1149 \\
81 \\
5.4\end{array}$ & $\begin{array}{l}0.31 \\
1156 \\
89 \\
4.4\end{array}$ & $\begin{array}{l}0.29 \\
1161 \\
95 \\
3.5\end{array}$ & $\begin{array}{l}0.28 \\
1161 \\
109 \\
2.7\end{array}$ & $\begin{array}{c}0.25 \\
1157 \\
(\mathrm{c}) \\
(\mathrm{c})\end{array}$ & $\begin{array}{l}\cdots . . \\
\cdots \\
\cdots \\
\cdots-.\end{array}$ & $\begin{array}{l}\cdots-. \\
\cdots \\
\cdots\end{array}$ \\
\hline 34 & $\begin{array}{l}\text { tetragonal } \\
\mathrm{PbTiO}_{3} \\
\mathrm{PbZrO}_{3} \\
\mathrm{PbO}: \mathrm{SnO}_{2}\end{array}$ & $\begin{array}{l}48.0 \\
32.0 \\
20.0\end{array}$ & $\begin{array}{l}k_{\mathrm{r}} \\
\text { f.c. } \\
d_{31} \\
g_{31}\end{array}$ & $\begin{array}{l}0.39 \\
1129 \\
72 \\
9.2\end{array}$ & $\begin{array}{l}0.39 \\
1122 \\
75 \\
8.5\end{array}$ & $\begin{array}{l}0.38 \\
1118 \\
78 \\
8.4\end{array}$ & $\begin{array}{r}0.38 \\
1118 \\
82 \\
7.5\end{array}$ & $\begin{array}{l}0.38 \\
1121 \\
85 \\
7.0\end{array}$ & $\begin{array}{l}0.36 \\
1128 \\
85 \\
6.2\end{array}$ & $\begin{array}{r}0.34 \\
1140 \\
87 \\
5.4\end{array}$ & $\begin{array}{l}0.33 \\
1147 \\
92 \\
4.6\end{array}$ & $\begin{array}{l}0.30 \\
1151 \\
96 \\
3.8\end{array}$ & $\begin{array}{l}0.25 \\
1152 \\
104 \\
2.6\end{array}$ & $\begin{array}{l}0.24 \\
1153 \\
102 \\
2.3\end{array}$ & $\begin{array}{l}\ldots . . \\
\cdots \cdots \\
\cdots \cdots\end{array}$ & $\begin{array}{l}\cdots \\
\cdots \cdots \\
\cdots \cdots\end{array}$ & $\begin{array}{l}\cdots \\
\cdots \\
\cdots \cdots \\
\cdots \cdots\end{array}$ \\
\hline 35 & $\begin{array}{l}\text { rhombohedral } \\
\mathrm{PbTiO}_{3} \\
\mathrm{PbZrO}_{3} \\
\mathrm{PbO}_{3} \mathrm{SnO}_{2}\end{array}$ & $\begin{array}{l}46.0 \\
34.0 \\
20.0\end{array}$ & $\begin{array}{l}k_{\mathrm{r}} \\
\text { f.c. } \\
d_{31} \\
\mathrm{~g}_{31}\end{array}$ & $\begin{array}{l}0.38 \\
1139 \\
61 \\
9.5\end{array}$ & $\begin{array}{l}0.39 \\
1125 \\
68 \\
9.0\end{array}$ & $\begin{array}{l}0.39 \\
1127 \\
72 \\
8.8\end{array}$ & $\begin{array}{l}0.38 \\
1120 \\
75 \\
8.1\end{array}$ & $\begin{array}{l}0.38 \\
1122 \\
76 \\
7.6\end{array}$ & $\begin{array}{l}0.37 \\
1129 \\
81 \\
6.8\end{array}$ & $\begin{array}{l}0.36 \\
1119 \\
88 \\
6.1\end{array}$ & $\begin{array}{l}0.35 \\
1116 \\
102 \\
4.9\end{array}$ & $\begin{array}{l}0.30 \\
1120 \\
108 \\
3.6\end{array}$ & $\begin{array}{l}0.18 \\
1126 \\
92 \\
1.5\end{array}$ & $\begin{array}{l}\cdots \\
\cdots \\
\cdots \cdots \\
\cdots \cdots\end{array}$ & $\begin{array}{l}\cdots \\
\cdots \\
-\cdots \\
-\cdots\end{array}$ & $\begin{array}{l}\cdots \\
\cdots \\
\cdots-. \\
-\cdots\end{array}$ & $\begin{array}{l}\cdots \\
\cdots \\
\cdots-. \\
\cdots\end{array}$ \\
\hline 41 & $\begin{array}{l}\text { tetragonal } \\
\mathrm{PbTiO}_{3} \\
\mathrm{PbZrO}_{3} \\
\mathrm{PbO}: \mathrm{SnO}_{2}\end{array}$ & $\begin{array}{l}47.25 \\
22.75 \\
30.00\end{array}$ & $\begin{array}{l}k_{\mathrm{r}} \\
\text { f.c. } \\
d_{31} \\
\mathrm{~g}_{31}\end{array}$ & $\begin{array}{l}0.40 \\
1133 \\
\quad 74 \\
7.7\end{array}$ & $\begin{array}{l}0.39 \\
1128 \\
79 \\
7.2\end{array}$ & $\begin{array}{r}0.39 \\
1132 \\
81 \\
6.7\end{array}$ & $\begin{array}{c}0.38 \\
1134 \\
83 \\
6.3\end{array}$ & $\begin{array}{l}0.35 \\
1147 \\
80 \\
5.5\end{array}$ & $\begin{array}{l}0.34 \\
1156 \\
79 \\
5.0\end{array}$ & $\begin{array}{l}0.32 \\
1166 \\
80 \\
4.4\end{array}$ & $\begin{array}{l}0.29 \\
1172 \\
82 \\
3.6\end{array}$ & $\begin{array}{l}0.26 \\
1175 \\
86 \\
2.7\end{array}$ & $\begin{array}{l}0.18 \\
1181 \\
73 \\
1.5\end{array}$ & $\begin{array}{l}\ldots . \\
\cdots \cdots \\
\cdots \cdots\end{array}$ & $\begin{array}{l}\ldots \\
\cdots \cdots \\
\cdots \cdots\end{array}$ & $\begin{array}{l}\ldots . \\
\cdots \\
\cdots\end{array}$ & $\begin{array}{l}\cdots \\
\cdots \\
\cdots \cdots \\
\cdots\end{array}$ \\
\hline 42 & $\begin{array}{l}\text { rhombohedral } \\
\mathrm{PbTiO}_{3} \\
\mathrm{PbZrO}_{3} \\
\mathrm{PbO}: \mathrm{SnO}_{2}\end{array}$ & $\begin{array}{l}45.5 \\
24.5 \\
30.0\end{array}$ & $\begin{array}{l}k_{\mathrm{r}} \\
f_{\mathrm{c}} . \\
\mathrm{d}_{31} \\
\mathrm{~g}_{31}\end{array}$ & $\begin{array}{l}0.38 \\
1147 \\
65 \\
9.1\end{array}$ & $\begin{array}{l}0.39 \\
1137 \\
71 \\
8.6\end{array}$ & $\begin{array}{l}0.38 \\
1134 \\
76 \\
7.9\end{array}$ & $\begin{array}{r}0.38 \\
1132 \\
80 \\
7.4\end{array}$ & $\begin{array}{l}0.37 \\
1138 \\
81 \\
6.7\end{array}$ & $\begin{array}{l}0.36 \\
1136 \\
87 \\
6.1\end{array}$ & $\begin{array}{l}0.35 \\
1136 \\
97 \\
5.1\end{array}$ & $\begin{array}{l}0.30 \\
1142 \\
104 \\
3.5\end{array}$ & $\begin{array}{l}0.24 \\
1152 \\
101 \\
2.3\end{array}$ & $\begin{array}{l}\cdots \\
\cdots \\
\cdots \cdots \\
\cdots\end{array}$ & $\begin{array}{l}\cdots \\
\cdots \\
\cdots \\
\cdots-.\end{array}$ & $\begin{array}{l}\cdots \\
\cdots \\
\cdots \\
\cdots\end{array}$ & $\begin{array}{l}\ldots . . \\
\cdots \\
\cdots \cdots \\
\cdots\end{array}$ & $\begin{array}{l}\cdots-. \\
\cdots \cdots \\
\cdots \cdots\end{array}$ \\
\hline 53 & $\begin{array}{l}\text { tetragonal } \\
\mathrm{PbTiO}_{3} \\
\mathrm{PbZrO}_{3} \\
{\mathrm{PbO}: \mathrm{SnO}_{2}}\end{array}$ & $\begin{array}{l}46.5 \\
13.5 \\
40.0\end{array}$ & $\begin{array}{l}k_{\mathrm{r}} \\
f_{f} \cdot \mathrm{c}_{31} \\
\mathrm{~d}_{31} \\
\mathrm{~g}_{31}\end{array}$ & $\begin{array}{l}0.36 \\
1106 \\
63 \\
8.2\end{array}$ & $\begin{array}{l}0.35 \\
1108 \\
70 \\
7.5\end{array}$ & $\begin{array}{l}0.34 \\
1108 \\
72 \\
7.1\end{array}$ & $\begin{array}{l}0.34 \\
1111 \\
75 \\
6.7\end{array}$ & $\begin{array}{l}0.32 \\
1120 \\
73 \\
5.4\end{array}$ & $\begin{array}{l}0.30 \\
1127 \\
73 \\
5.4\end{array}$ & $\begin{array}{l}0.29 \\
1132 \\
75 \\
4.8\end{array}$ & $\begin{array}{l}0.25 \\
1139 \\
73 \\
3.4\end{array}$ & $\begin{array}{l}0.17 \\
1150 \\
67 \\
1.7\end{array}$ & $\begin{array}{l}\ldots \\
- \\
\cdots \\
\ldots\end{array}$ & $\begin{array}{l}\cdots \\
\cdots \\
\cdots \\
\cdots\end{array}$ & $\begin{array}{l}\cdots \\
\cdots \\
\cdots \\
\cdots\end{array}$ & $\begin{array}{l}\cdots \\
\cdots \\
\cdots \\
\cdots\end{array}$ & $\begin{array}{l}\cdots \cdots \\
\cdots \cdots \\
\cdots \cdots\end{array}$ \\
\hline 54 & $\begin{array}{l}\text { rhomboheiral } \\
\mathrm{PbTiO}_{3} \\
\mathrm{PbZrO}_{3} \\
\mathrm{PbO}: \mathrm{SnO}_{2}\end{array}$ & $\begin{array}{l}45.0 \\
15.0 \\
40.0\end{array}$ & $\begin{array}{c}k_{r} \\
f_{f} . \\
d_{31} \\
g_{31}\end{array}$ & $\begin{array}{r}0.36 \\
1098 \\
61 \\
8.9\end{array}$ & $\begin{array}{l}0.35 \\
1093 \\
63 \\
7.8\end{array}$ & $\begin{array}{r}0.36 \\
1090 \\
69 \\
7.6\end{array}$ & $\begin{array}{l}0.35 \\
1089 \\
72 \\
7.1\end{array}$ & $\begin{array}{l}0.34 \\
1092 \\
75 \\
6.3\end{array}$ & $\begin{array}{l}0.32 \\
1099 \\
75 \\
5.5\end{array}$ & $\begin{array}{l}0.31 \\
1104 \\
83 \\
4.6\end{array}$ & $\begin{array}{l}0.23 \\
1122 \\
79 \\
2.5\end{array}$ & $\begin{array}{l}0.14 \\
1168 \\
54 \\
1.2\end{array}$ & $\begin{array}{l} \\
\cdots \\
\cdots \cdots \\
\cdots \cdots\end{array}$ & $\begin{array}{l}\cdots \\
\cdots \\
\cdots \cdots \\
-\cdots\end{array}$ & $\begin{array}{l}\cdots \\
\cdots \\
\cdots \cdots \\
-\cdots\end{array}$ & $\begin{array}{l}\cdots \\
\cdots \\
\cdots \\
\cdots\end{array}$ & $\begin{array}{l}\cdots \\
\cdots \cdots \\
\cdots \cdots\end{array}$ \\
\hline 69 & $\begin{array}{l}\text { tetragonal } \\
\mathrm{PbTiO}_{3} \\
\mathrm{PbHfO}_{3}\end{array}$ & $\begin{array}{l}52.5 \\
47.5\end{array}$ & $\begin{array}{l}k_{\mathrm{r}} \\
\text { f.c. } \\
\mathrm{d}_{31} \\
\mathrm{~g}_{31}\end{array}$ & $\begin{array}{r}0.37 \\
1110 \\
59 \\
8.8\end{array}$ & $\begin{array}{l}0.36 \\
1110 \\
60 \\
8.3\end{array}$ & $\begin{array}{c}0.36 \\
1106 \\
63 \\
8.1\end{array}$ & $\begin{array}{l}0.36 \\
1108 \\
66 \\
7.7\end{array}$ & $\begin{array}{l}0.36 \\
1112 \\
69 \\
7.3\end{array}$ & $\begin{array}{l}0.34 \\
1119 \\
69 \\
6.4\end{array}$ & $\begin{array}{l}0.33 \\
1125 \\
74 \\
5.4\end{array}$ & $\begin{array}{l}0.32 \\
1130 \\
74 \\
4.9\end{array}$ & $\begin{array}{l}0.29 \\
1133 \\
(\mathrm{c}) \\
(\mathrm{c})\end{array}$ & $\begin{array}{l}0.27 \\
1131 \\
\cdots \cdots \\
\cdots\end{array}$ & \begin{tabular}{c}
0.23 \\
1130 \\
\hdashline
\end{tabular} & $\begin{array}{c}0.20 \\
1201 \\
\cdots\end{array}$ & . & $\begin{array}{c} \\
\ldots \\
\cdots\end{array}$ \\
\hline 70 & $\begin{array}{l}\text { rhombohedral } \\
\mathrm{PbTiO}_{3} \\
\mathrm{PbHfO}_{3}\end{array}$ & $\begin{array}{l}50 \\
50\end{array}$ & $\begin{array}{l}\mathrm{k}_{\mathrm{r}} \\
\text { f.c. } \\
\mathrm{d}_{31} \\
\mathrm{~g}_{31}\end{array}$ & $\begin{array}{r}0.38 \\
1111 \\
54 \\
10.3\end{array}$ & $\begin{array}{l}0.38 \\
1097 \\
60 \\
9.6\end{array}$ & $\begin{array}{r}0.37 \\
1097 \\
61 \\
9.2\end{array}$ & $\begin{array}{c}0.38 \\
1089 \\
66 \\
9.1\end{array}$ & $\begin{array}{c}0.38 \\
1089 \\
71 \\
8.5\end{array}$ & $\begin{array}{l}0.37 \\
1088 \\
75 \\
8.2\end{array}$ & $\begin{array}{c}0.36 \\
1086 \\
80 \\
7.1\end{array}$ & $\begin{array}{c}0.34 \\
1088 \\
92 \\
5.7\end{array}$ & $\begin{array}{c}0.33 \\
1086 \\
(c) \\
(\mathrm{c})\end{array}$ & \begin{tabular}{c}
0.31 \\
1089 \\
\hdashline \\
\end{tabular} & \begin{tabular}{c}
0.24 \\
1103 \\
\hdashline \\
\end{tabular} & $\begin{array}{c}0.09 \\
1137 \\
- \\
\end{array}$ & $\begin{array}{c}\ldots \\
\cdots \\
\cdots \\
\cdots\end{array}$ & $\begin{array}{l}\cdots \\
\cdots \\
\cdots\end{array}$ \\
\hline
\end{tabular}

\footnotetext{
a Units: $k_{\mathrm{r}}$ dimensionless.

f. c. cycle-meters $=$ kilocycle millimeters

$\mathrm{d}_{31} \mathrm{~m} / \mathrm{v}\left(\mathrm{x} 10^{-12}\right)$ or coulombs/new ton $\left(\times 10^{-12}\right)$.

$g_{31}$ voltmeters/newton $\left(\times 10^{-3}\right)$

b Low value probably caused by either experimental error or minor cross coupling to some flexure mode.

c Large dielectric losses prevented dielectric constant measurement necessary to obtain these values.

d Values were measured after varying times of storage.
}

An attempt was made to observe hysteresis loops. With 60-cycle alternating fields of about 80 volts RMS per 0.001 in., the patterns produced for these specimens at room temperature were those of linear dielectrics. Because they are isostructural with $\mathrm{PbZrO}_{3}$, show dielectric constant maxima, and have no dielectric hysteresis, it must be concluded that the
$\mathrm{PbZrO}_{3}-\mathrm{PbO}: \mathrm{SnO}_{2}$ solid solutions crystallize in a single antiferroelectric perovskite solid-solution phase.

\section{d. $\mathrm{PbTiO}_{3}-\mathrm{PbZrO}_{3}-\mathrm{PbO}: \mathrm{SnO}_{2}$}

Ceramic specimens of these ternary solid solutions were examined by X-ray diffraction powder analyses. The solid solutions rich in $\mathrm{PbTiO}_{3}$ were tetragonal 
with $\mathrm{c} / \mathrm{a}>1$. If a sufficient quantity of $\mathrm{PbZrO}_{3}$ plus $\mathrm{PbO}: \mathrm{SnO}_{2}$ was added in any proportion, the tetragonal phase was replaced by a rhombohedral one with $\alpha<90^{\circ}$. These lattice parameters are shown in table 2. Thus, the phase boundary that characterizes both the $\mathrm{PbTiO}_{3}-\mathrm{PbZrO}_{3}$ and the $\mathrm{PbTiO}_{3}-$ $\mathrm{PbO}: \mathrm{SnO}_{2}$ systems persists into the ternary field and runs smoothly from one binary phase boundary to the other, as shown in figure 1. The areas of stability of the various phases at room temperature can also be seen in this diagram. Along this morphotropic boundary, the dielectric constant and the radial coupling coefficient were enhanced, as can be seen from tables 3 and 4 .

Because the $\mathrm{PbZrO}_{3}-\mathrm{PbO}: \mathrm{SnO}_{2}$ binaries were antiferroelectric, there must be another morphotropic boundary between that phase and the rhombohedral one. This does, in fact, exist. As found by hysteresis studies at the 30 mole percent $\mathrm{PbO}: \mathrm{SnO}_{2}$ level, the compositional position of this boundary seems to be slightly temperature dependent (fig. 11). The composition with 56 mole percent $\mathrm{PbZrO}_{3}$ remained ferroelectric from $-50^{\circ} \mathrm{C}$ to the Curie temperature, $140^{\circ}$ C. A composition containing 59.5 percent $\mathrm{PbZrO}_{3}$ remained ferroelectric up to about $125^{\circ} \mathrm{C}$, then became antiferroelectric, and remained so up to $160^{\circ} \mathrm{C}$, its Curie temperature. At the 63 percent $\mathrm{PbZrO}_{3}$ composition, antiferroelectricity existed from $-50^{\circ} \mathrm{C}$ to its Curie point. For the composition with 59.5 mole percent $\mathrm{PbZrO}_{3}$, at temperatures in its antiferroelectric range, anomalous hysteresis loops of the type first described by Shirane, Sawaguchi, and Takagi [17] were obtained. These are characterized by a linear central region which opens up to two minor loops, one at each extreme. This type of loop shows the existence of a ferroelectric phase at an energy level slightly above the antiferroelectric phase. Instantaneously during each cycle the crystal becomes ferroelectric when a threshold voltage is exceeded, then becomes antiferroelectric when the instantaneous voltage diminishes again.

In a narrow region along the rhombohedral edge of the phase boundary, the X-ray powder patterns showed a small content of the tetragonal phase, in addition to the major rhombohedral phase. It is not clear whether this represents equilibrium or disequilibrium for these specimens. A smooth curve has been drawn through the Curie temperatures obtained near the morphotropic ferroelectric phase boundary in figure 11, because the data were not sufficient to attach any significance to the spread of values.

It was found that the specimens of compositions adjacent to the phase boundary, and containing 40 and 50 mole percent $\mathrm{PbO}: \mathrm{SnO}_{2}$, were very difficult to mature, even though many heat-treatment schedules were tried. The boundary compositions on the 40 mole percent $\mathrm{PbO}: \mathrm{SnO}_{2}$ level with 13.5 percent $\mathrm{PbZrO}_{3}$ and 15 percent $\mathrm{PbZrO}_{3}$, were made with fairly low absorption only after repeated heating; the compositions on the 50 mole percent $\mathrm{PbO}: \mathrm{SnO}_{2}$ level with 6.25 percent $\mathrm{PbZrO}_{3}$ and 7.5 percent
$\mathrm{PbZrO}_{3}$ were not matured (See table 1). There was no apparent reason for this; volatilization was low and there was no evidence of other dissociation. The materials remained single-phase perovskites. Because the fired density of these compositions may be less than optimum, their dielectric and piezoelectric properties probably do not adequately represent those of the composition itself.

As the phase boundary is traced from the $\mathrm{Pb}(\mathrm{Ti}, \mathrm{Zr}) \mathrm{O}_{3}$ composition at 55 mole percent $\mathrm{PbZrO}_{3}$ toward the $\mathrm{Pb}(\mathrm{Ti}, \mathrm{Sn}) \mathrm{O}_{3}$ composition at 55 mole percent $\mathrm{PbO}: \mathrm{SnO}_{2}$, the dielectric constant, shown in figure 12 , and the radial coupling coefficient values, shown in figure 13, remain high through 30 mole percent $\mathrm{PbO}: \mathrm{SnO}_{2}$, then diminish, for reasons stated in the preceding paragraph. The maxima on both of these figures help delineate the phase boundary. In the region where the coupling coefficient is high, it can be noted that addition of $\mathrm{PbO}: \mathrm{SnO}_{2}$ tends to increase the room-temperature dielectric constant. For a given value of coupling coefficient, this would tend to lower $g_{31}$ and raise $d_{31}$, because $K^{2}$ equals the product of $g, d$ and $Y$. Therefore, at room temperature, the rhombohedral binary composition 55 mole percent $\mathrm{PbZrO}_{3}$ has the best $g_{31}$ value, while the tetragonal ternary composition with 30 percent $\mathrm{PbO}: \mathrm{SnO}_{2}$ and 22.75 percent $\mathrm{PbZrO}_{3}$, has the highest $d_{31}$ constant. High $d$ constant is important for a transducer used as a driver or generator of motion; high $g$ constant is important for sensing elements where motion or force must be converted to an electrical signal. However, even though optimum $d$ constant may be important, the decrease in Curie temperature that accompanies substitution of $\mathrm{Sn}^{4+}$ for $\mathrm{Zr}^{4+}$ in this system must be regarded as a disadvantage offsetting the increase in $d_{31}$.

Figures 14 and 15 show the dependence of the electromechanical properties of compositions on the join containing 30 mole percent $\mathrm{PbO}: \mathrm{SnO}_{2}$ with 22.75 percent $\mathrm{PbZrO}_{3}$ and with 24.5 percent $\mathrm{PbZrO}_{3}$, the limiting tetragonal and rbombohedral compositions respectively. The values plotted in these figures are given in table 5. For all the boundary compositions, no ferroelectric-ferroelectric polymorphic phase transformations were noted at temperatures below their Curie point. Thus, there are no major irregularities in the curve of resonance frequency as a function of operating temperature. In fact, figure 15 shows that the resonance frequency of the composition with 30 mole percent $\mathrm{PbO}: \mathrm{SnO}_{2}$ and 24.5 percent $\mathrm{PbZrO}_{3}$ only varies about 2 percent between $25^{\circ}$ and $225^{\circ} \mathrm{C}$. This is characteristic of all the limiting rhombohedral compositions in this system. A comparison of figures 14 and 15 with figures 5 and 6 will bring out the effects of the $\mathrm{PbO}: \mathrm{SnO}_{2}$ substitution for $\mathrm{PbZrO}_{3}$ in this system.

\section{e. $\mathrm{PbTiO}_{3}-\mathrm{PbHfO}_{3}$}

Specimens of $\mathrm{PbTiO}_{3}-\mathrm{PbHfO}_{3}$ solid solutions were made in ceramic form. Here, too, a morphotropic inversion was observed somewhere between $47 \frac{1}{2}$ and 50 mole percent $\mathrm{PbHfO}_{3}$. Structurally, compositions in this system proved to be very similar to those in the $\mathrm{Pb}(\mathrm{Zr}, \mathrm{Ti}) \mathrm{O}_{3}$ series. Increasing content of 
lead hafnate, as it replaces lead titanate, lowers the Curie temperature and, at room temperature, decreases the tetragonal c/a ratio. The equimolar composition was predominantly rhombohedral with a small content of the tertagonal phase. Solid solutions richer than this in $\mathrm{PbHfO}_{3}$ were rhombohedral. It is recognized that other morphotropic phase boundaries may exist for compositions high in $\mathrm{PbHfO}_{3}$, but they are outside the range of compositions investigated. Figure 16 shows the locus of the Curie points for the various compositions, and is a first approximation of the solid-state phase diagram.

As the composition approached the morphotropic phase boundary, the room-temperature dielectric constant and the radial coupling coefficient become maximum, as indicated in figure 17. Here, too, radial coupling coefficient values of almost 0.4 were observed. Specimens of these $\mathrm{Pb}(\mathrm{Hf}, \mathrm{Ti}) \mathrm{O}_{3}$ compositions had relatively high leakage during polarization, presumably because of their $\mathrm{Fe}_{2} \mathrm{O}_{3}$ content. The magnitude of the polarizing field (table 4) was varied to accommodate specimens of different quality. As a result, comparison between specimens of a series of compositions is hindered. It seems clear, however, that desirable values of coupling coefficient typify the boundary compositions. Figures 18 and 19 show the change of the piezoelectric properties of the boundary compositions with temperature. The values plotted in these figures are given in table 5 .

Additional experiments to make these specimens with a highly-pure grade of $\mathrm{HfO}_{2}$ proved to be disappointing. The specimens were difficult to mature, and inferior values of dielectric constant and coupling coefficient were obtained.

\section{Summary}

It has been observed that the dielectric constant and the radial coupling coefficient exhibit maxima at compositions approaching the morphotropic boundaries, an effect similar to that observed at polymorphic phase boundaries. Electromechanical properties as a function of temperature are summarized in table 5 for the specimens close to the morphotropic boundaries. These compositions exhibit high Curie temperatures, $175^{\circ} \mathrm{C}$ or above and high radial coupling coefficient, greater than 0.33 , as observed in all the specimens except those occuring in the $\mathrm{PbTiO}_{3}$ $\mathrm{PbO}: \mathrm{SnO}_{2}$ system. The limiting rhombohedral composition $\mathrm{Pb}\left(\mathrm{Ti}_{.45} \mathrm{Zr}_{.55}\right) \mathrm{O}_{3}$, exhibited a high radial coupling coefficient for temperatures as high as $275^{\circ} \mathrm{C}$. This composition also exhibits the highest $g_{31}$ constant as measured at room temperature. The limiting tetragonal composition in the 30 mole percent $\mathrm{PbO}: \mathrm{SnO}_{2}$ series exhibits the highest $d_{31}$ constant. The frequency constant is most stable for the limiting rhombohedral composition on the 30 mole percent $\mathrm{PbO}: \mathrm{SnO}_{2}$ level, although all the limiting rhombohedral compositions are good. Properties of solid solution ceramics in the system $\mathrm{Pb}(\mathrm{Ti}, \mathrm{Hf}) \mathrm{O}_{3}$ were found to be similar to those found in the $\mathrm{Pb}(\mathrm{Ti}, \mathrm{Zr}) \mathrm{O}_{3}$ system.

It has been shown in the present study that ferroelectric solid-solution ceramics, having their com- position close to a morphotropic phase boundary, exhibit high dielectric constant and relatively good piezoelectric properties. Furthermore, if polymorphic inversions below the Curie temperature do not occur, the desirable properties are stable over a wide range of temperature. Examples of this phenomena have been observed for the solid solution series $\mathrm{PbTiO}_{3}-\mathrm{PbZrO} \mathrm{O}_{3}-\mathrm{PbO}: \mathrm{SnO}_{2}$ and $\mathrm{PbTiO}_{3}-\mathrm{PbHfO}_{3}$.

\section{References}

[1] H. D. Megaw, Origin of ferroelectricity in barium titanate and other perovskite-type crystals, Acta Cryst. [6] 5, 739-748 (1952).

[2] H. Jaffe, Titanate ceramies for electromechanical purposes, Ind. Eng. Chem. [2], 42 264-268 (1950).

[3] G. Shirane and K. Suzuki, Crystal structure of $\mathrm{Pb}(\mathrm{Zr}-\mathrm{Ti}) \mathrm{O}_{3}$, J. Phys. Soc. Japan [3] \%, 333 (1952).

[4] S. T. Bowden, The phase rule and phase reactions, (Macmillan and Co., Ltd., London, 1945), p. 167.

[5] E. Sawaguchi, Ferroelectricity versus antiferroelectricity in the solid solutions of $\mathrm{PbZrO}_{3}$ and $\mathrm{PbTiO}_{3}, \mathrm{~J}$. Phys. Soc. Japan [5] 8, 615-629 (1953).

[6] B. Jaffe, R. S. Roth, and S. Marzullo, Properties of piezoelectric lead zirconate-lead titanate solid solution ceramics, Am. Ceram. Soc. Bull. [3] 33, Program p. 41 (1954) Abstract Only.

[7] B. Jaffe, R. S. Roth and S. Marzullo, Piezoelectric properties of lead zirconate-lead titanate solid-solution ceramics, J. Appl. Phys. [6] 25, 809-810 (1954).

[8] S. Roberts, Dielectric properties of lead zirconate and barium-lead zirconate. J. Am. Ceram. Soc. [2] 33, 63 (1950)

[9] G. R. Shelton, E. N. Bunting, B. Jaffe, and L. Kopell, Unpublished 1951-52 progress reports.

[10] W. P. Mason, Piezoelectric crystals and their applications to ultrasonics, (D. Van Nostrand Co., New York, N. Y., 1950)

[11] G. Shirane, S. Hoshino, and K. Suzuki, Crystal structure of lead titanate and of barium-lead titanate, J. Phys. Soc. Japan [6] 5, 453 (1950).

[12] S. V. Naray-Szabo, Structure of $\mathrm{ABO}_{3}$ compounds-sister structures, Naturw. [39/40] 31, 466 (1943).

[13] S. S. Cole and H. Espenscheid, Lead titanate; crystal structure, temperature of formation, and specific gravity data, J. Phys. Chem. [3] 41, 445-451 (1937).

[14] S. Roberts (private communication, Aug. 1953).

[15] S. V. Naray-Szabo, The structure type of perovskite $\mathrm{CaTiO}_{3}$, Naturw. [16/18] 31, 202 (1943).

[16] S. Roberts, Dielectric properties of lead zirconate and barium-lead zirconate, J. Am. Ceram. Soc. [2] 33, 63 (1950).

[17] G. Shirane, E. Sawaguchi, and Y. Takagi, Dielectric properties of lead zirconate, Phys. Rev. [3] 84, 476 (1951).

[18] E. Sawaguchi, H. Maniwa, and S. Hoshino, Antiferroelectric structure of lead zirconate, Phys. Rev. [5] 83, 1078 (1951).

[19] C. Kittel, Theory of antiferroelectric crystals, Phys. Rev. [5] 82, 729-732 (1951).

[20] H. D. Megaw, Crystal structure of double oxides of the perovskite type, Proc. Phys. Soc. London [326] 58, part $\boldsymbol{2}, 133-152(1946)$.

[21] W. W. Coffeen, Ceramic and dielectric properties of the stannates. J. Am. Ceram. Soc. [7] 36, 207-214 (1953).

[22] I. Naray-Szabo, The perovskite structure family, Müegyetemi Közlemények [1] 1, 30-41 (1947).

[23] A. Byström, X-ray studies on lead sesquioxide, $\mathrm{Pb}_{2} \mathrm{O}_{3}$, Arkiv Kemi, Mineral Geol. [23] 18A, 1-8 (1945).

[24] G. Shirane and R. Pepinsky, Phase transitions in antiferroelectric $\mathrm{PbHfO}_{3}$, Phys. Rev. [4] 91, 812-815 (1953).

[25] C. B. Sawyer and C. H. Tower, Rochelle Salt as a dielectric, Phys. Rev. [3] 35, 269-273 (1930).

[26] S. Nomura and S. Sawada, Study on the dielectric substances having high permittivity (Part III) I. Study on the Solid solution of titanates, Rept. Inst. Sci. and Technol., Univ. Tokyo $7,83-86$ (1953). 


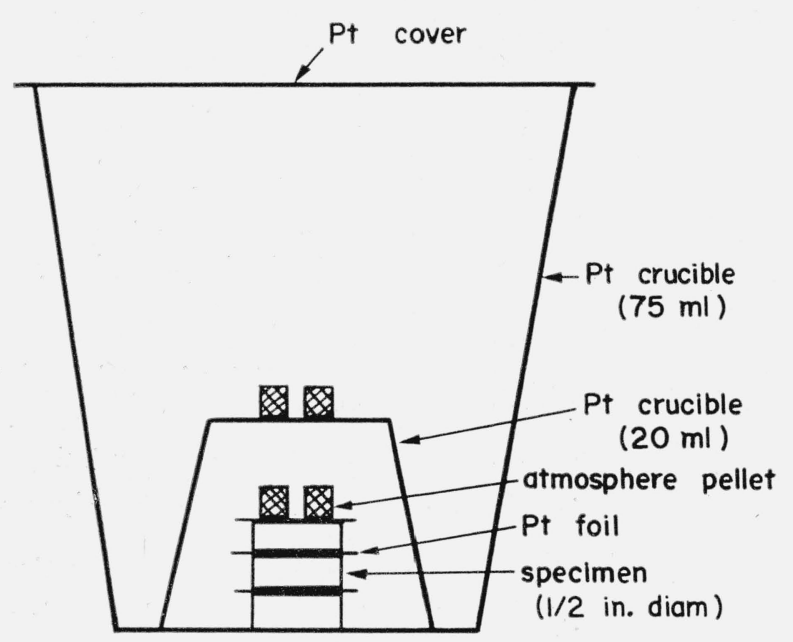

Figure 2. Cross-section through the platinum crucible used to fire $\mathrm{PbO}$ ceramics.

Cross-hatched rectangles represent $\mathrm{PbO}: \mathrm{ZrO}_{2}$ pellets slightly enriched in $\mathrm{PbO}$ necessary to maintain a proper $\mathrm{PbO}$ atmosphere.
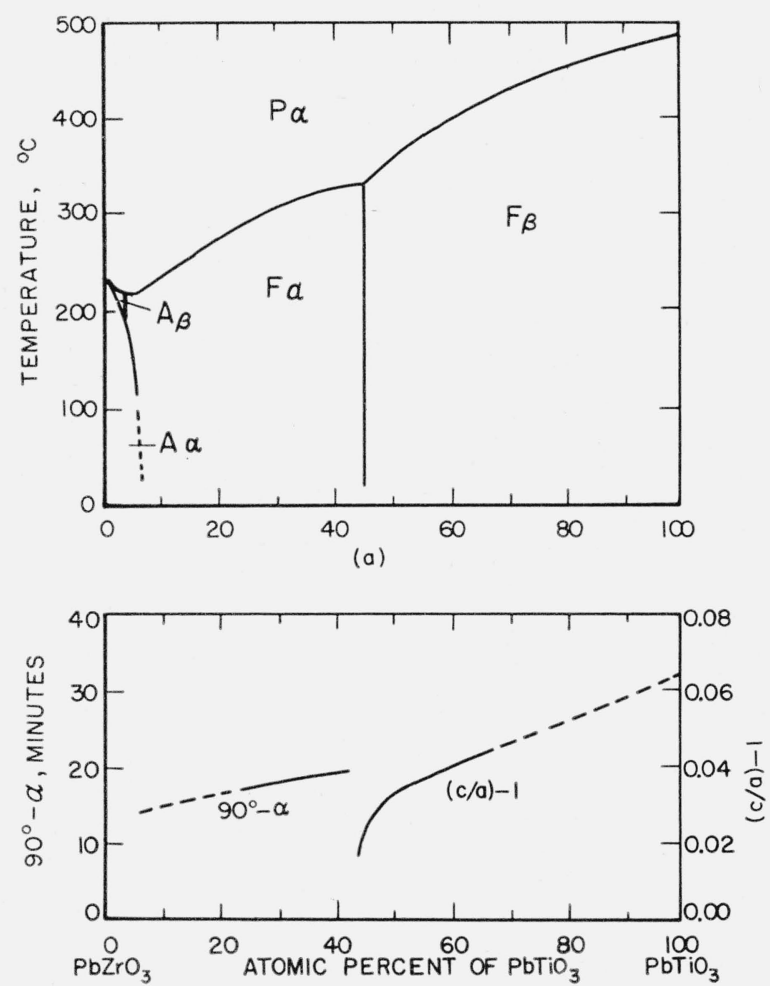

(b)

FIgurE 3. a-Solid-state phase diagram for $\mathrm{PbTiO}_{3}-\mathrm{PbZrO}_{3}$ solid solutions. b-Crystallographic parameters showing distortion from ideal cubic perovskite structure, giving deviation of rhomb angles, from $90^{\circ}$ in rhombohedral range and tetragonal distortion in tetragonal range.

These diagrams are adapted from Sawaguchi [5] on lead zirconate-lead titanate solid solutions. $\mathrm{P}_{\alpha}$-paraelectric, cubic; $\mathrm{F}_{\alpha}$-ferroelectric, rhombohedral; $\mathrm{F}_{\beta}$-ferroelectric, tetragonal; $\mathrm{A}_{\alpha}$ and $\mathrm{A}_{\beta}$-antiferroelectric areas.

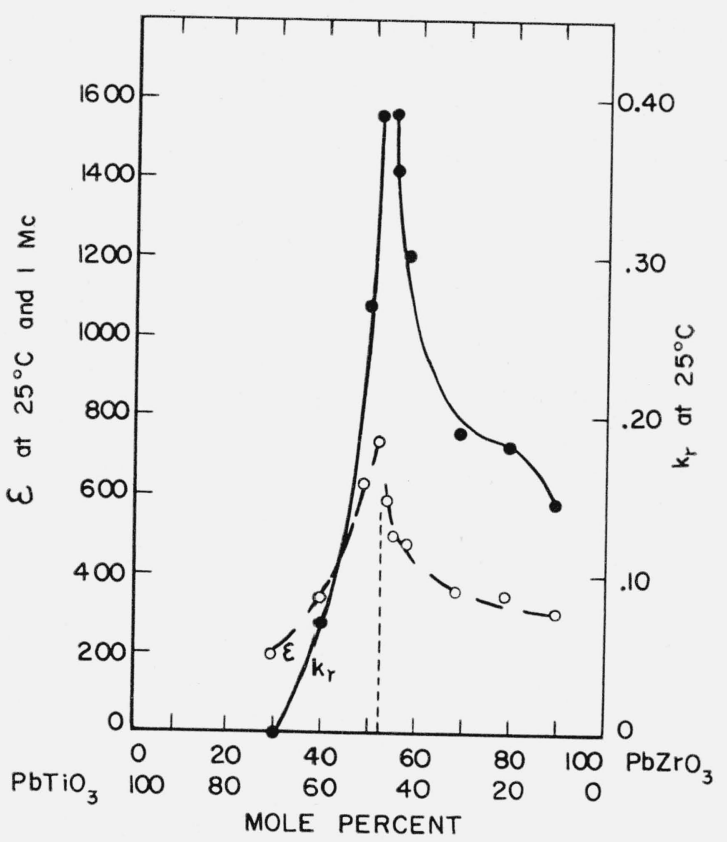

FIGURE 4. Dielectric constant $(\epsilon)$ and the radial coupling coupling coefficient $\left(k_{\mathrm{r}}\right)$ at $25^{\circ} \mathrm{C}$ and $1 \mathrm{Mc}$, for $\mathrm{PbTiO}_{3}$ $\mathrm{PbZrO}_{3}$ solid-solution ceramics.

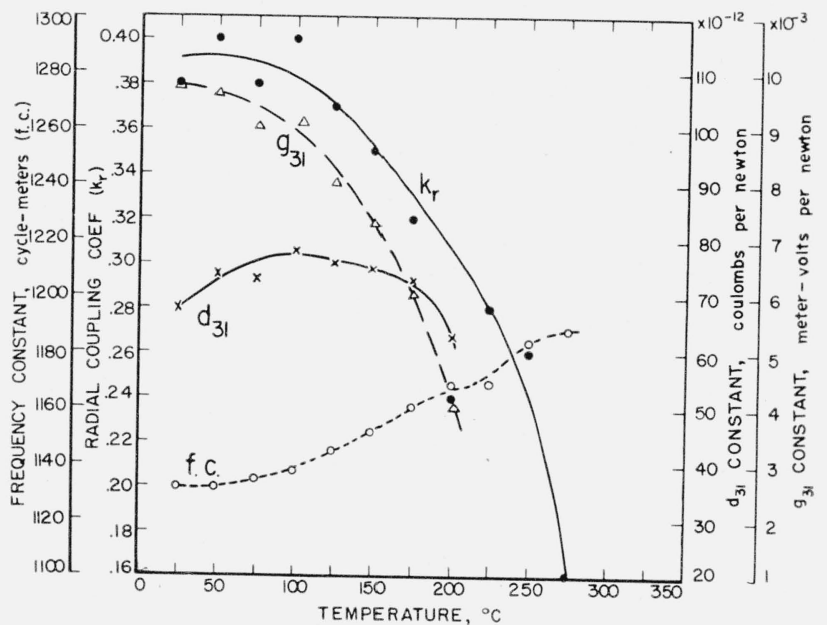

Figure 5. Piezoelectric properties at elevated temperatures for limiting tetrogonal composition containing 52.5 mole percent $\mathrm{PbZrO}_{3}+47.5$ mole percent $\mathrm{PbTiO}_{3}$ in solid solution. 


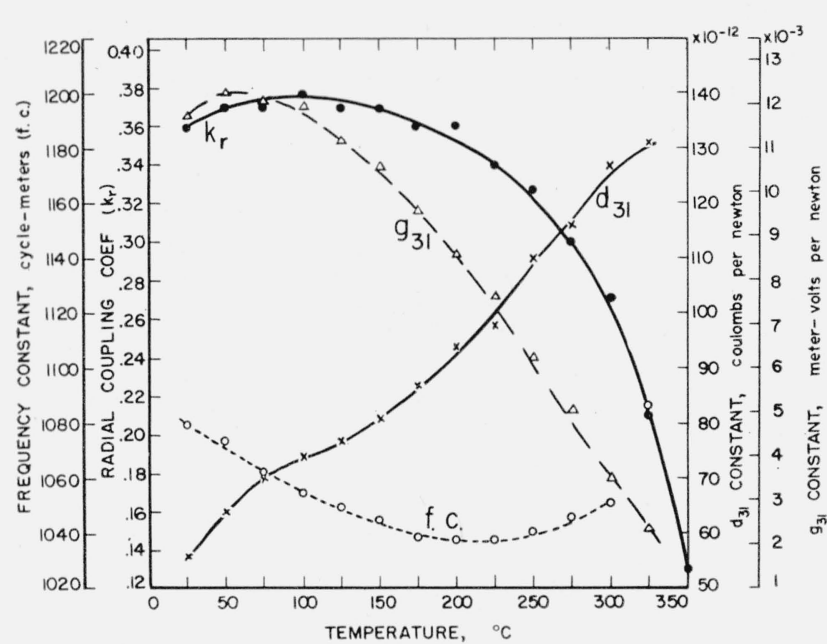

Figure 6. Piezoelectric properties at elevated temperatures for limiting rhombohedral composition containing 55 mole percent $\mathrm{PbZrO}_{3}+45$ mole percent $\mathrm{PbTiO}_{3}$ in solid solution.

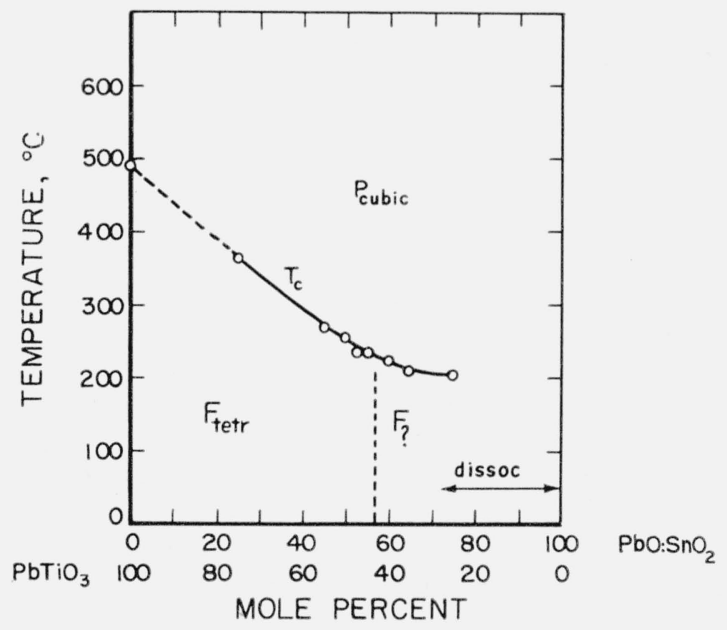

Figure 7. Curve showing Curie temperature $\left(T_{c}\right)$ and regions of stability of ferroelectric $\mathrm{PbTiO}_{3}-\mathrm{PbO}: \mathrm{SnO}_{2}$ solid solution ceramics.

Value of Curie point for $\mathrm{PbTiO}_{3}$ obtained from literature. $\mathrm{P}_{\text {cubio-paraelectric; }}$

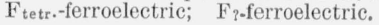

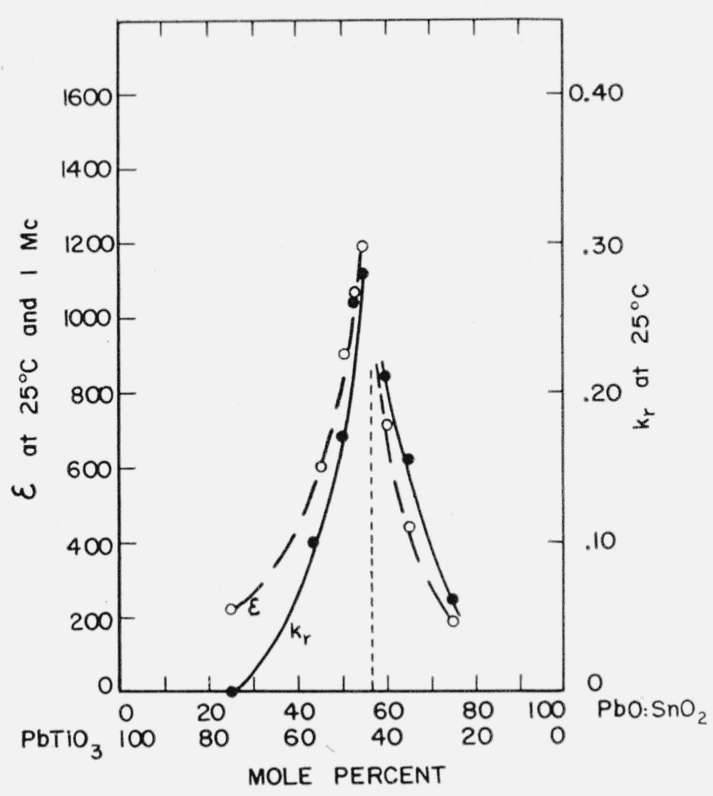

FIGURE 8. Dielectric constant $(\epsilon)$ and radial coupling coefficient $\left(k_{\mathrm{r}}\right)$, at $25^{\circ} \mathrm{C}$ and $1 \mathrm{Mc}$, for $\mathrm{PbTiO}_{3}-\mathrm{PbO}: \mathrm{SnO}_{2}$ solid solution ceramics.

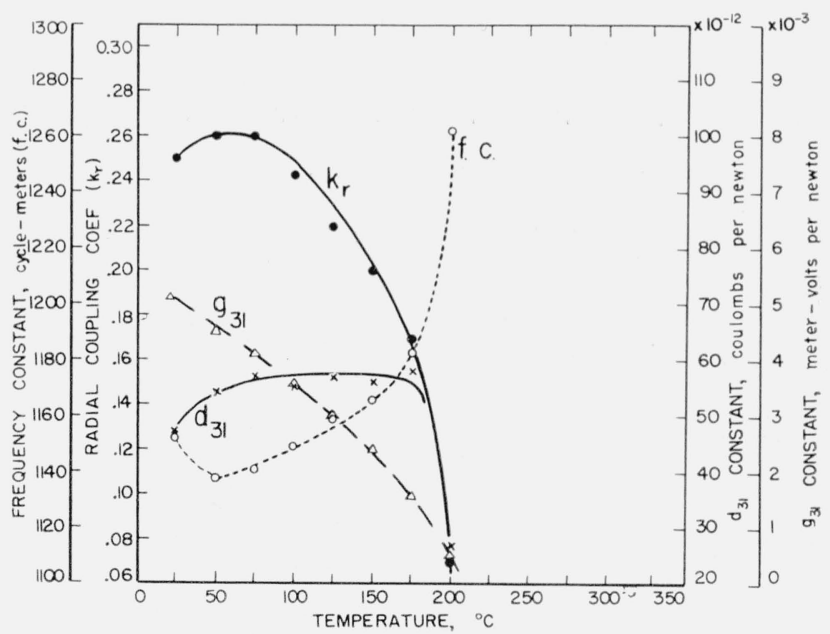

Figure 9. Piezoelectric properties at elevated temperatures for limiting tegragonal composition containing 55 mole percent $\mathrm{PbO}: \mathrm{SnO}_{2}+45$ mole percent $\mathrm{PbTiO}_{3}$ in solid solution. 


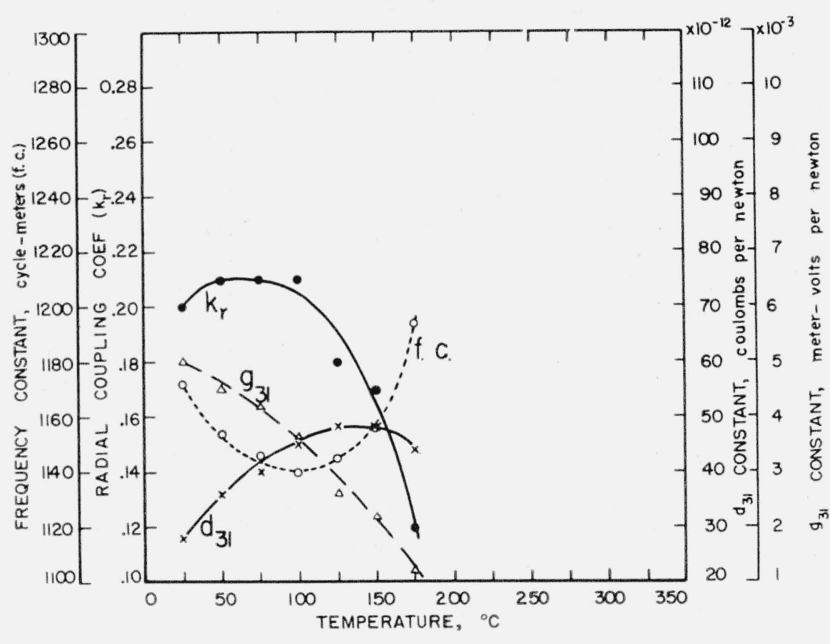

Figure 10. Piezoelectric properties at elevated temperatures for the pseudocubic composition containing 60 mole percent $\mathrm{PbO}: \mathrm{SnO}_{2}+40$ mole percent $\mathrm{PbTiO}_{3}$ in solid solution.

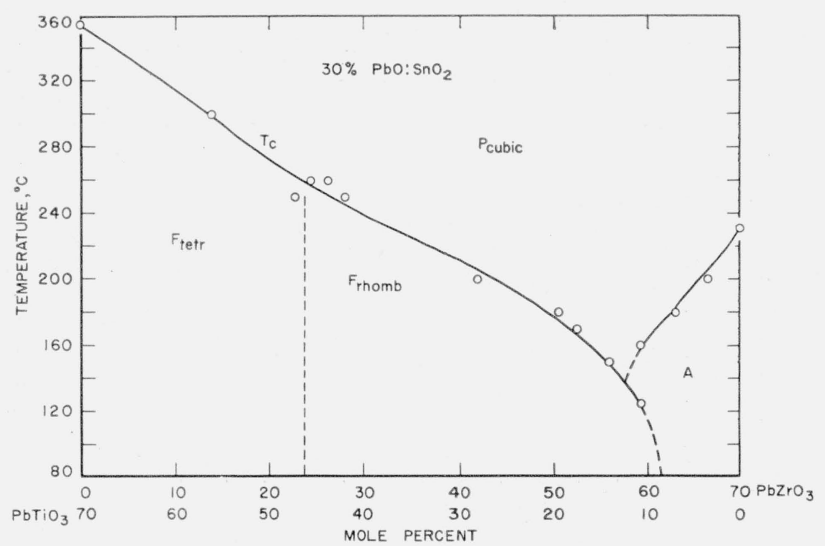

FIgure 11. Phases in the solid-solution series of $\mathrm{PbTiO}_{3}$. $\mathrm{PbZrO}_{3}$ at the 30 mole percent $\mathrm{PbO}: \mathrm{SnO}_{2}$ level, showing the morphotropic boundaries between the ferroelectric tetragonal $\left(F_{t e t r .}\right)$ ferroelectric-rhombohedral $\left(F_{r h o m b}\right)$ and the antiferroelectric area $A$, as well as the polymorphic boundary of the paraelectric cubic $\left(P_{c u b i c}\right)$ perovskite-type field.

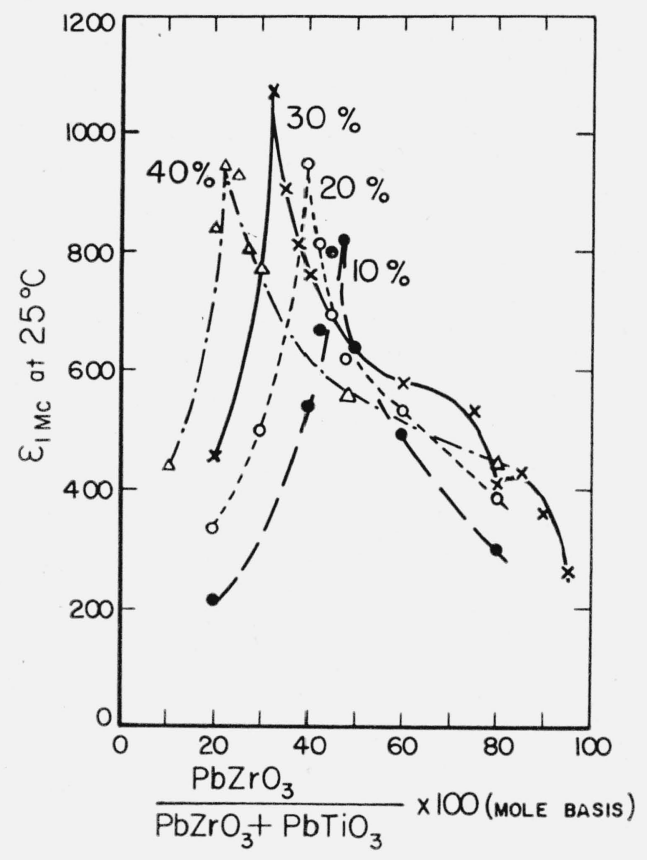

Figure 12. Dielectric constant $(\epsilon)$ at $25^{\circ} C$ and $1 \mathrm{Mc}$ for ternary solid solutions containing 10, 20, 30, and 40 mole percent $\mathrm{PbO}: \mathrm{SnO}_{2}$.

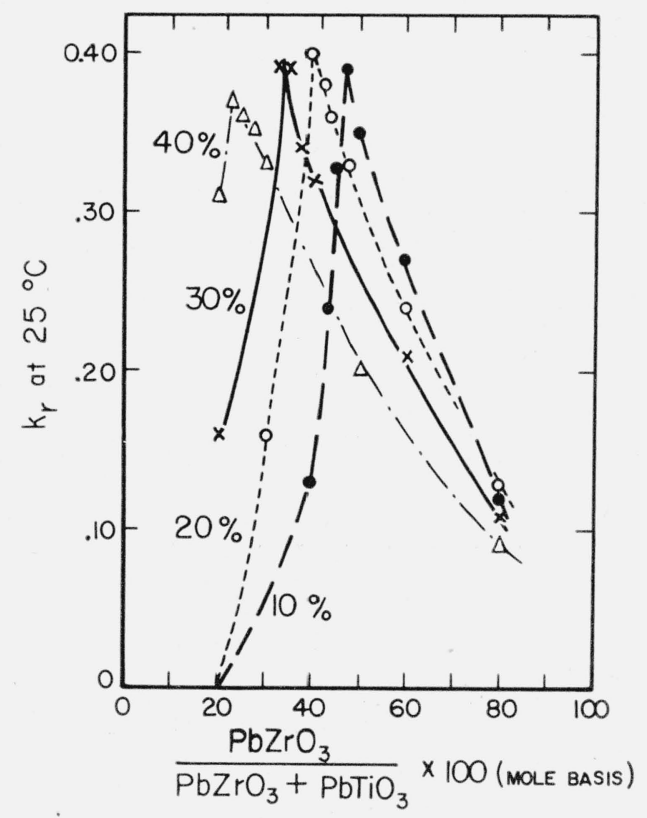

Figure 13. Radial coupling coefficient $\left(k_{r}\right)$ at $25^{\circ} \mathrm{C}$ for ternary solid solutions containing 10, 20, 30, and 40 mole percent $\mathrm{PbO}: \mathrm{SnO}_{2}$ 


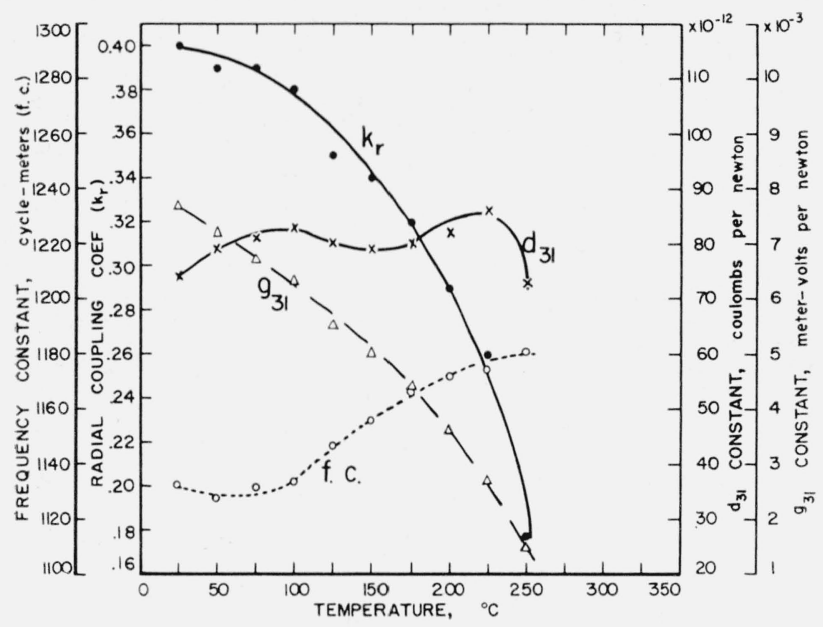

Figure 14. Piezolectric properties at elevated temperatures for for the tetragonal composition containing 30 mole percent $\mathrm{PbO}: \mathrm{SnO}_{2}$ and 22.75 percent $\mathrm{PbZrO}_{3}$, near the ferroelectricferroelectric phase boundary shown in the previous figure.

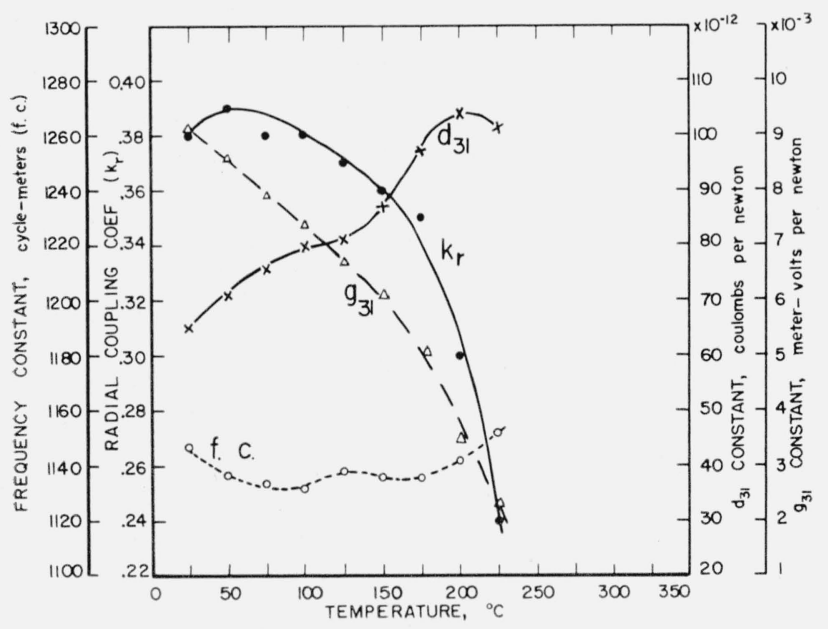

FIGURE 15. Piezoelectric properties at elevated temperatures for the rhombohedral composition containing 30 mole percent $\mathrm{PbO}: \mathrm{SnO}_{2}$ and 24.5 percent $\mathrm{PbZrO}_{3}$, near the ferroelectricferroelectric phase boundary shown in figure 11.

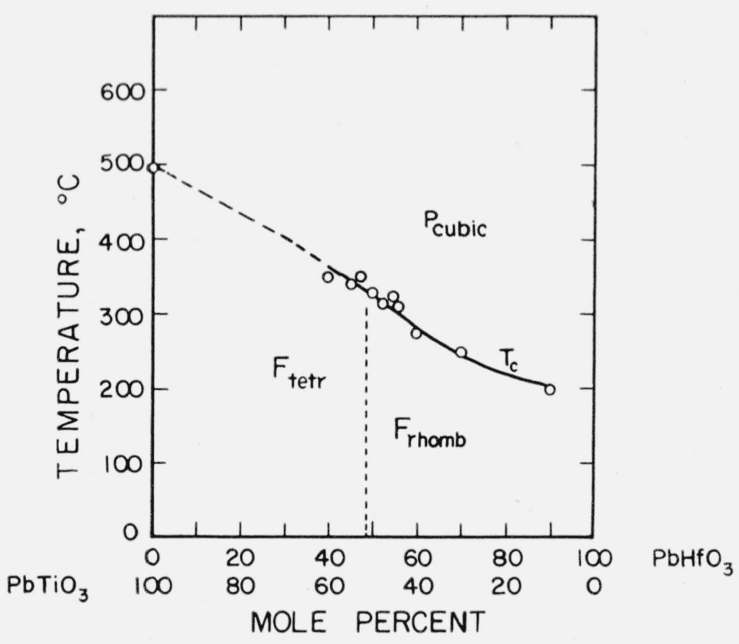

Figure 16. Curve showing Curie temperature $\left(T_{c}\right)$ of ferroelectric $\mathrm{PbTiO}_{3}-\mathrm{PbHfO}_{3}$ solid-solution ceramics.

This is an indication of part of the solid state phase diagram. $\mathrm{P}_{\text {cubio-paraelectric; }}$ $\mathrm{F}_{\text {tetr }}$ and $\mathrm{F}_{\text {rhomb-ferroelectric. }}$

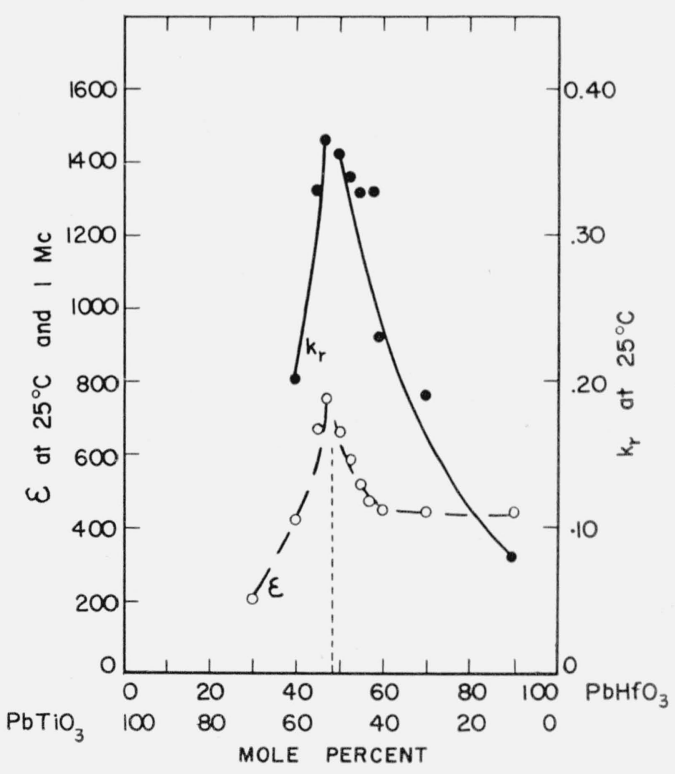

Figure 17. Dielectric constant $(\epsilon)$ and radial coupling coefficient $\left(k_{r}\right)$, at $25^{\circ} \mathrm{C}$ and $1 \mathrm{Mc}$, for $\mathrm{PbTiO}_{3}-\mathrm{PbHfO}_{3}$ solid-solution ceramics. 


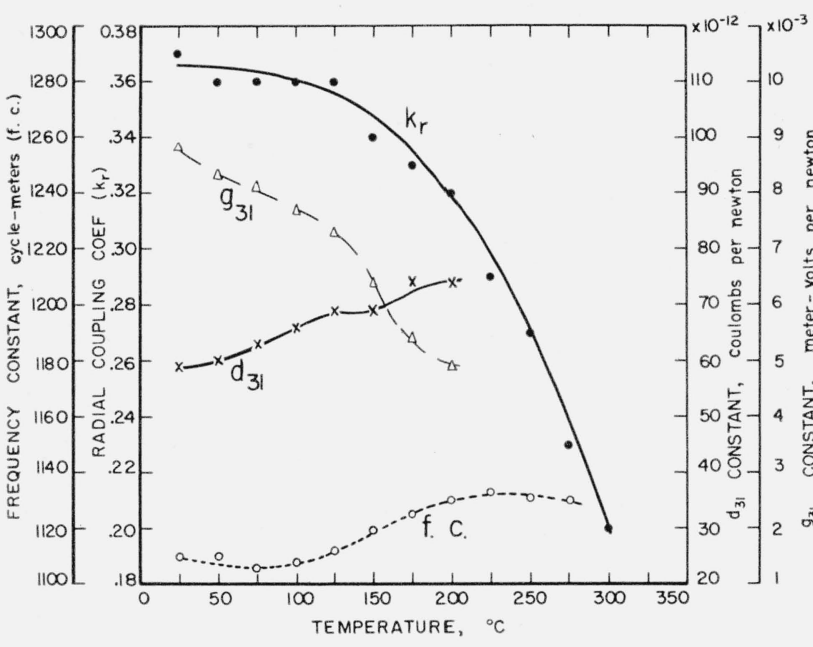

Figure 18. Piezoelectric properties at elevated temperatures for the limiting tetragonal composition containing 47.5 mole percent $\mathrm{PbHfO}_{3}+52.5$ mole percent $\mathrm{PbTiO}_{3}$ in solid solution.

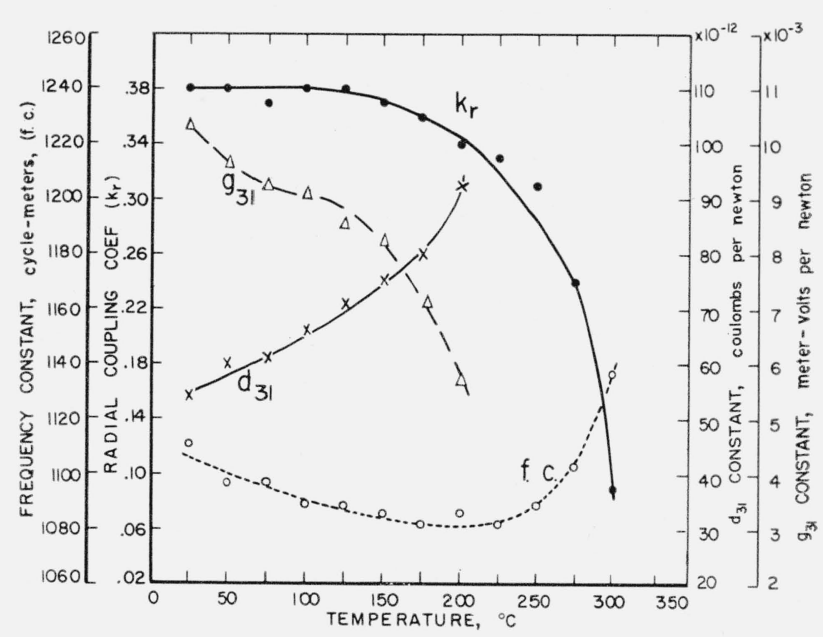

Figure 19. Piezoelectric properties at elevated temperatures for the limiting rhombohedral composition containing equimolar amounts of $\mathrm{PbHFO}_{3}$ and $\mathrm{PbTiO}_{3}$ in solid solution.

Washington, July 8, 1955. 